\title{
Redox Systems Biology: Harnessing the Sentinels of the Cysteine Redoxome
}

\author{
Jason M. Held ${ }^{1-3}$
}

\begin{abstract}
Significance: Cellular redox processes are highly interconnected, yet not in equilibrium, and governed by a wide range of biochemical parameters. Technological advances continue refining how specific redox processes are regulated, but broad understanding of the dynamic interconnectivity between cellular redox modules remains limited. Systems biology investigates multiple components in complex environments and can provide integrative insights into the multifaceted cellular redox state. This review describes the state of the art in redox systems biology as well as provides an updated perspective and practical guide for harnessing thousands of cysteine sensors in the redoxome for multiparameter characterization of cellular redox networks.

Recent Advances: Redox systems biology has been applied to genome-scale models and large public datasets, challenged common conceptions, and provided new insights that complement reductionist approaches. Advances in public knowledge and user-friendly tools for proteome-wide annotation of cysteine sentinels can now leverage cysteine redox proteomics datasets to provide spatial, functional, and protein structural information. Critical Issues: Careful consideration of available analytical approaches is needed to broadly characterize the systems-level properties of redox signaling networks and be experimentally feasible. The cysteine redoxome is an informative focal point since it integrates many aspects of redox biology. The mechanisms and redox modules governing cysteine redox regulation, cysteine oxidation assays, proteome-wide annotation of the biophysical and biochemical properties of individual cysteines, and their clinical application are discussed.

Future Directions: Investigating the cysteine redoxome at a systems level will uncover new insights into the mechanisms of selectivity and context dependence of redox signaling networks. Antioxid. Redox Signal. 32, 659-676.
\end{abstract}

Keywords: systems biology, cysteines, redox, proteomics, oxidation, mathematical modeling

\section{Redox Systems Biology: Goals}

T The GOAL OF REDOX SYSTEMS BIOLOGY, defined here as integrative profiling or modeling aimed toward comprehensive, multiparameter understanding of the cellular redox state, is to address the dimensionality and reductionist challenges of redox biology. While systems biology often does not test clear hypotheses, it is best suited to answer many important redox questions that require an integrative solution. Is there a global redox setpoint or is each redox module (Figs. 1 and 2) independent (2)? How can bottlenecks of redox biochemistry be efficiently identified and confirmed in cells, such as contexts in which nicotinamide adenine dinucleotide phosphate (NADPH) or glutathione (GSH) becomes limiting (92)? What are the design principles of redox signaling and what distinguishes redox signaling from oxidative stress (76)? What specific roles does redox biology play as a hallmark of cancer (65) and other diseases? What sets redox homeostatic setpoints, what triggers their adaptation in cancer and other diseases (35), and how can therapeutic intervention restore them? How personalized or individualized are redox processes? What are the key buffers between redox modules enabling regulatory specificity and providing context dependence to redox signaling networks?

Departments of ${ }^{1}$ Medicine and ${ }^{2}$ Anesthesiology, Washington University School of Medicine in St. Louis, St. Louis, Missouri.

${ }^{3}$ Siteman Cancer Center, Washington University School of Medicine in St. Louis, St. Louis, Missouri. 
a

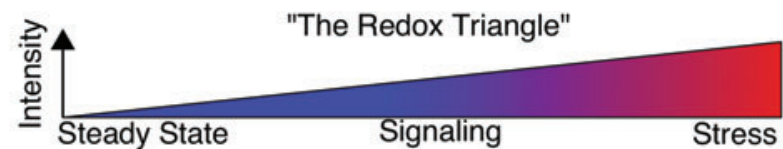

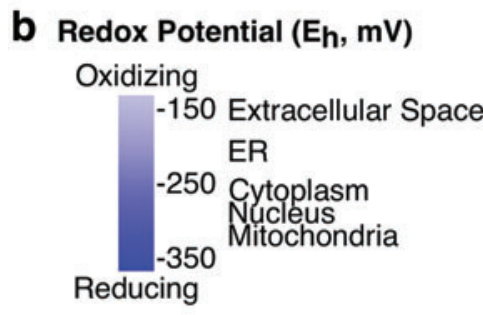

C Temporal Regulation $\begin{aligned} \text { Seconds } & \text { ROS flashes } \\ \text { Minutes } & - \text { Growth factor signaling } \\ \text { Hours } & \text { Circadian rhythm } \\ \text { Sustained } & \text { Chronic Inflammation } \\ & \text { aging }\end{aligned}$

\begin{tabular}{|c|c|}
\hline Redox Couples & $\begin{array}{c}\text { NADPH:NADP+ } \\
\text { GSH:GSSG } \\
\text { Cys:CySS }\end{array}$ \\
\hline ROS Producers & $\begin{array}{c}\text { NADPH oxidases } \\
\text { Dual oxidases } \\
\text { Mitochondrial ETC } \\
\text { Nitric oxide synthases }\end{array}$ \\
\hline $\begin{array}{c}\text { Redox Second } \\
\text { Messengers }\end{array}$ & $\begin{array}{c}\mathrm{O}_{2} \\
\mathrm{H}_{2} \mathrm{O}_{2} \\
\mathrm{NO} \\
\mathrm{H}_{2} \mathrm{~S}\end{array}$ \\
\hline Antioxidants & $\begin{array}{l}\text { Peroxiredoxins } \\
\text { Thioredoxin } \\
\text { GSH reductase } \\
\text { GSH peroxidases }\end{array}$ \\
\hline $\begin{array}{c}\text { Redox } \\
\text { Effectors }\end{array}$ & $\begin{array}{c}\text { Transcription factors } \\
\text { Kinases } \\
\text { GTPases }\end{array}$ \\
\hline
\end{tabular}

FIG. 1. Redox systems biology: curse of dimensionality. (a) The redox triangle is a common representation of the cellular redox state, with the $Y$-axis generally vague as is typical. (b) Redox potentials (millivolts, $\mathrm{mV}$ ) vary widely between organelles and (c) across temporal scales. (d) Cellular redox components include redox couples, ROS producers, redox active second messengers, antioxidants, and redox effectors. ROS, reactive oxygen species. Color images are available online.
Broader goals of redox systems biology include generating new hypotheses, defining the design principles of redox signaling, and confronting common (mis)conceptions, which are discussed throughout. One essential challenge for redox systems biology is to supersede the ubiquitous "redox triangle" model (Fig. 1a). In the redox triangle, the primary driver of redox biology is the level of a vague redox stimulus, usually inferred as reactive oxygen species (ROS) that directs trinary outputs of cell steady state, signaling, and stress.

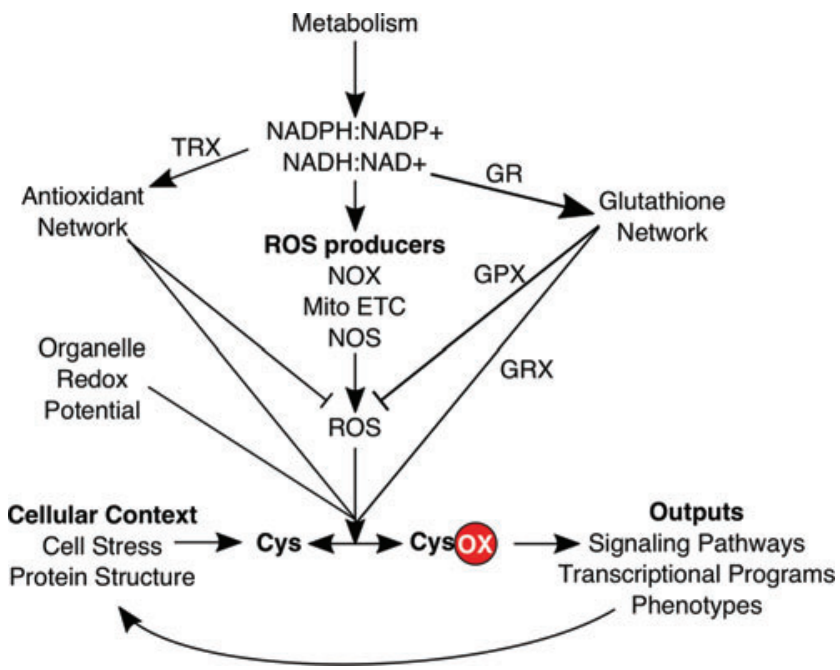

FIG. 2. Cysteines as sentinels of multiple redox modules: ROS, redox couples, cellular location and context, and metabolism. Simplified network diagram of the redox and nonredox inputs and outputs tuned to redox regulation of the cysteine redoxome. Key proteins and molecules are indicated. mito, mitochondria; ox, oxidized. Color images are available online.
While simple, the triangle representation of redox biology is misleading and puts a misplaced emphasis on ROS levels (20) instead of circuitry, network logic, and cellular location. Focusing on ROS levels, in turn, propagates the "antioxidant paradoxes" of cancer, aging, and diabetes $(9,25,109,143)$. Systems-level understanding of redox biology is a key to accurately simplify visualization of the essential network structures of redox biology (38) and to delineate and focus on the functional regulatory nodes and circuitry based on specific cellular contexts.

\section{Redox Biology: Systems-Level Challenges}

Redox reactions are essential for life as key transducers of cell signaling and metabolism. Redox processes are full of contradiction, however, defying easily interpretable causeeffect logic, and are often nonlinear, ultrasensitive, or hysteretic $(55,138,163,172)$. Discerning which redox module(s) are responsible for a specific function or phenotype and delineating how the module(s) function codependently with other cellular components remain challenging. The interconnectivity crucial to the structure of cellular redox networks taxes the reductionist model of breaking down systems into individual components to isolate a single root. Simplification is further hindered since many redox processes cannot be accurately modeled outside of a cell (137), yet within a cell there are many different redox processes that are not in thermodynamic equilibrium (80) and vary across organelles (60) (Fig. 1b). Kinetic competition among many reactions drives selectivity of redox processes, but adds another layer of complexity that is difficult to model as simply and intuitively as signal transduction and transcriptional networks $(2,183)$. In addition, redox cycles occur on diverse temporal scales since circadian rhythm, cell cycle, and light/ dark cycles alter cellular redox state over the course of hours $(39,63,167,190)$, chronic diseases alter redox state over 
months and years (57), yet significant perturbation to redox homeostasis can be resolved in minutes or less to return to steady state $(28,139)$ (Fig. 1c). The relationship and interdependence of redox processes throughout the cell and across different time scales remain poorly understood.

Cellular redox systems include a wide array of components that are cooperative (190), but hierarchical and have varying specificities and kinetics (Fig. 1d). These can be grouped into five primary categories: (i) small molecule redox couples (NADPH:NADP+, NADH:NAD+, GSH: oxidized glutathione [GSSG]) that are often catalytically coupled to the activity of (ii) antioxidant proteins such as peroxiredoxins (PRDXs), thioredoxin (TRX), and GSH-utilizing enzymes. (iii) Small metabolites often derived from oxygen such as superoxide $\left(\mathrm{O}_{2}^{-\bullet}\right)$, hydrogen peroxide $\left(\mathrm{H}_{2} \mathrm{O}_{2}\right)$, and nitric oxide $\left({ }^{\bullet} \mathrm{NO}\right)$. Some of these play clear roles as signaling second messengers but others, such as the hydroxyl radical, lack the specificity or reversibility needed for signaling (48). Hydrogen sulfide $\left(\mathrm{H}_{2} \mathrm{~S}\right)$ and cysteine are small molecule effectors that participate in redox processes but do not use oxygen $(10,17)$. (iv) The major endogenous sources of ROS for redox signaling include NADPH oxidases (NOXs), dual oxidases (DUOXs), nitric oxide synthases, and the mitochondrial electron transport chain. (v) The downstream effectors of redox biology, which may be directly or indirectly redox regulated, include transcription factors such as nuclear factor erythroid 2-related factor 2 (NRF2), hypoxia-inducible factor 1-alpha (HIF1 $\alpha)$, aryl hydrocarbon receptor, and nuclear factor NF-kappa-B p100 subunit $(\mathrm{NF} \kappa \mathrm{B})$, kinases such as MAP kinases (MAPKs), and GTPases (68).

Redox biology suffers from the "curse of dimensionality" due to the many integrated components and high spatiotemporal diversity. While new chemical and imaging technologies with increased chemical $(4,120,124,125,137,139$, $140)$ or spatiotemporal specificity $(103,137,166,193)$ have unequivocally increased our knowledge of redox biology, building of integrative, cell-level, bottom-up models of redox biology with these narrowly focused techniques is experimentally untenable $(20,177,193)$. For example, the current state of the art approach combining genetically encoded sensors for NADPH:NADP+, NADH:NAD+, $\mathrm{H}_{2} \mathrm{O}_{2}$ levels, and/or the thiol redox state in cells is limited by fluorescent spectral overlap for each fluorophore, and thus each parameter must be measured in nonoverlapping cellular compartments (193). Assaying additional spatial combinations of redox processes requires generating new cell lines with a different set of genetically encoded sensors. Using these tools to approach a full accounting of the cellular redox state is therefore experimentally challenging. ROS assays similarly suffer from spectral limitations that restrict parallel analysis of different ROS, localization, or other redox parameters. The ability to introduce fluorophores with specific redox readouts on demand would help alleviate these issues. Sallin et al. took a step toward this goal by utilizing Snifit tags, biosensors of cellular NAD+ levels, and the NADPH:NADP+ ratio, which are semisynthetic and can be flexibly conjugated to target proteins in live cells in real time similar to Halo- or SNAP tags (132).

\section{Redox Systems Biology: Metabolism}

Constraint-based mathematical modeling with flux balance analysis (FBA) is a common technique to simplify the complexity of biochemical networks and predict the steady state flux distribution of metabolites (116). FBA is especially useful to determine the capacity of metabolic networks (41, $42,45,191)$ and narrow down possible model topologies $(2$, $116,172)$ when combined with experimental results, including public data. FBA coupled with carbon metabolite tracing revealed that, unexpectedly, serine-driven 1-carbon metabolism contributes as much to NADPH production as the pentose phosphate shunt (PPP) via the activity of methylenetetrahydrofolate dehydrogenase (42).

A hallmark of redox processes is their dynamic, yet robust mechanisms maintaining homeostasis $(28,66)$. Elucidating how the cellular redox system transitions to respond to perturbations, transduces adaptive signaling, and either restores or adjusts homeostasis remains an important challenge. To examine the mechanism of Escherichia coli's rapid response to stress, Christodoulou et al. quantified 30 metabolites at 10-s intervals up to 1 min after stimulation with high levels of $\mathrm{H}_{2} \mathrm{O}_{2}$ (28). FBA of glycolysis and the PPP that leveraged publicly available rate constants generated a candidate regulatory model focused on a negative interaction between glucose-6-phosphate dehydrogenase (G6PDH) and NADPH. The authors proposed, and subsequently verified, that $\mathrm{H}_{2} \mathrm{O}_{2}$ stress decreases NADPH levels within seconds, relieving NADPH-dependent inhibition of G6PDH to increase flux through the PPP to restore NADPH levels. This study highlights the robustness of the publicly available redox kinetic data and the power of computational modeling to in silico evaluate many potential redox components and narrow the set of possibilities down to be feasible for experimental testing. Kuehne et al. used time-resolved metabolic profiling to demonstrate that the same NADPH-G6PDH mechanism occurs in human fibroblasts in response to $\mathrm{H}_{2} \mathrm{O}_{2}$ or ultraviolet stress (88). This mechanism is distinct from oxidation of pyruvate kinase M2 C358, another redox-based mechanism inhibiting lower glycolysis to drive PPP flux and NADPH production (7) that likely works on a longer time scale to fine tune metabolism after it is restored initially by G6PDH activation. Notably, as these studies all focus on modeling oxidative stress, transitioning these systems-level approaches to nonstress conditions in which $\mathrm{H}_{2} \mathrm{O}_{2}$ drives redox signaling may reveal important new linkages between metabolic adaptation and sensors of redox alterations.

While the above studies focus on specific metabolic pathways, the ultimate goal of redox systems biology is largescale prediction and characterization of redox modules (38). Toward this goal, Lewis et al. modeled the NADPH-dependent cycling of the chemotherapeutic $\beta$-lapachone in head and neck cancer cells at the genome level using transcriptomic results (92). After modifying the Recon 2 metabolite network to include all NADPH metabolic reactions, the authors performed FBA of a network encompassing $>5000$ metabolites and 7000 reactions. Utilizing transcriptomic data from either matched head and neck cancer cell lines or primary tumors in The Cancer Genome Atlas that were either sensitive or resistant to $\beta$-lapachone or radiation, the authors simulated the effect of gene knockdown on drug sensitivity and predicted that isocitrate dehydrogenase 1 (IDH1) played an especially important role in NADPH production that mediated drug resistance. These predictions were experimentally verified by IDH1 knockdown in radiation-resistant cells, which routed NADPH flux through glutamate dehydrogenase 1/2. This study demonstrates the potential for genome-scale 
modeling of redox reactions in cell lines and primary tumors using public data. It is especially exciting that specific proteins and redox reactions that are limited by, or tuned to, such a complex redox hub as NADPH can be predicted.

To date, most redox systems biology advances have been limited to metabolism and use of mathematical modeling. While FBA has clear utility, it has notable limitations, including the inability to predict the dynamic changes in flux to a stimulus since kinetic parameters are not incorporated (116). Therefore, FBA only has limited ability to study redox signaling, which is dynamic, or vastly altered metabolic states that are not included in a generic map of human metabolism such as those that occur during carcinogenesis. In addition, constraints lie at the heart of FBA, and thus FBA requires complete information for all reaction components without any missing data. Protein expression therefore has limited utility for FBA because proteomics datasets have substantial amounts of missing data. Kinetic modeling is the primary alternative to FBA for metabolic systems in applications where time-dependent dynamics are of interest (2, 181). Finally, since only the successfully verified mathematical models are published, it is not possible to unbiasedly gauge the overall accuracy of these approaches. Communitywide, crowdsourced predictions such as DREAM challenges (100) offer an important opportunity to gauge the effectiveness of current mathematical redox modeling approaches.

\section{Redox Systems Biology: Beyond Metabolism}

Mathematical modeling and large-scale cysteine redox profiling have provided insight into the hierarchic interdependence of cellular antioxidant modules (83, 122, 123). Modeling $\mathrm{H}_{2} \mathrm{O}_{2}$ clearance in Jurkat cells, Adimora et al. discerned the relative contribution of various antioxidant modules to buffer $\mathrm{H}_{2} \mathrm{O}_{2}$ and the percentage of proteins that undergo S-glutathionylation versus disulfide formation (2). While catalase accounted for $<1 \%$ of $\mathrm{H}_{2} \mathrm{O}_{2}$ catabolism in Jurkat cells, Benfeitas et al. modeled that catalase and PRDXs contribute similarly to $\mathrm{H}_{2} \mathrm{O}_{2}$ metabolism in red blood cells (16). Taking a different approach, Le Moan et al. and Go et al. performed proteomic analysis of either yeast or mammalian cells, respectively, in which the TRX or GSH systems were selectively impaired, both finding that each antioxidant module controls the redox state of different subsets of cysteines in the proteome $(58,107)$. Systems-level metabolic profiling also revealed a new metabolic pathway providing cellular antioxidant capacity in normal hepatocytes that, defying expectation, survive even in the absence of the activity of two critical antioxidants, TRX and glutathione reductase (GR) (41). Eriksson et al. discerned that methionine is able to serve as the precursor of cysteine in TRX/GR-null livers, in contrast to the canonical model in which cysteine is taken up as its oxidized form cystine that is then reduced by the TRX/ GR system for use (41).

Redox systems biology techniques have facilitated development of biosensors for high-throughput, single cell analysis by identifying or directing evolution of NADPH-utilizing proteins. Siedler et al. developed an NADPH biosensor based on yellow fluorescent protein expression coupled to the SoxR protein promoter that is activated by increased NADPH (144). The authors performed a high-throughput, systematic screen of $\mathrm{NADPH}$-utilizing enzymes in large E. coli-mutant libraries to identify novel variant proteins with increased NADPH utilization that have potential application in metabolic engineering. Zhang et al. similarly developed a growth selection platform capable of screening $10^{8}$ variants per round of selection to identify NADPH-generating glyceraldehyde-3phosphate dehydrogenases with improved activity as well as direct evolution of a Lactobacillus delbrueckii lactate dehydrogenase variant with NADPH specificity instead of NADH (192).

$\mathrm{NRF} 2, \mathrm{NF} \kappa \mathrm{B}, \mathrm{HIF} 1 \alpha, \mathrm{MAPK}$, and forkhead box proteins constitute the master regulators of redox-sensitive transcriptional networks (68). These proteins work in coordination to initiate a transcriptional response that pleiotropically reprogram the cell's redox homeostatic setpoint(s), not just a simple upregulation of antioxidant capacity (68). In addition, sirtuins are protein deacetylases that play a unique role in redox biology by being tuned to NAD+ levels, capable of inducing ROS production and regulating protein acetylation (147). Application of systems biology beyond redox biology has identified new regulatory architectures in which hyperconnected master regulator proteins, via post-translational regulation, serve as integrative controllers of vast transcriptional networks in cell homeostasis, cancer, drug resistance (3, 23 , 174). These master regulatory proteins stably maintain complex phenotypes such as cancer despite the high genomic and proteomic heterogeneity across tumors, but notably are not frequently mutated or studied and difficult to identify using conventional experiments $(3,23,174)$. Application of these computational techniques to redox biology may uncover new redox regulator effectors that are responsible for higher level organization and interconnection of redox modules.

\section{Cysteines in the Proteome: Informative and Integrative Redox Sentinels}

All redox parameters would ideally be exhaustively and quantitatively characterized in space, time, and abundance to make a full accounting of the cellular redox status. However, the requisite tools to do so are lacking, and the extensive amount of time it would take to acquire all results with quantitative accuracy limits feasibility. Tangible advancement of redox systems biology will require careful consideration of feature selection, data dimensionality reduction, and collection of minimally redundant, maximally orthogonal data. For example, how and when do ROS measurements provide value if the sources and targets of the ROS are characterized, especially given the continued technical challenges of measuring ROS and their limited mechanistic value (20, 40)? More generally, how is the cellular redox state best assessed, and what redox parameter(s) are most effective for modeling and most efficiently determined experimentally?

Multiple properties of cysteines make them excellent and relatively specific redox sentinels due to their thiol side chain that can form seven stable oxidation states in vivo $(56,74$, 127), which has been extensively reviewed $(61,70,80,127$, 183). Experimental and bioinformatic analysis of the cysteine redoxome, defined as in Thamsen and Jakob (158) as the composite of all redox active cysteines, can integratively inform on many redox modules throughout the cell such as specific types of ROS, redox couples, ROS producers, and GSH-linked enzymes (80) (Fig. 2). For example, even in the absence of imaging data, cysteine redoxome analysis can 
spatially delineate redox alterations at the plasma membrane, mitochondria, and other organelles by examining which sentinel proteins localized to each organelle are redox regulated (Fig. 3).

Cysteines are oxidized by many ROS and redox effectors, including $\mathrm{O}_{2}^{-\bullet}, \mathrm{H}_{2} \mathrm{O}_{2},{ }^{\bullet} \mathrm{NO}, \mathrm{H}_{2} \mathrm{~S}$, Cys, and $\mathrm{GSH}$, to form specific adducts that can be selectively analyzed $(4,79,117$, $120,124,125,133,154)$. Recently, disulfide linkage between cysteines and the sulfur in coenzyme A (S-CoAlation) directly linking cysteine oxidation to metabolism was found to be a new cysteine redox modification established by antibody-based assays and mass spectrometry (165). Analysis of specific cysteine oxoforms can rapidly or comprehensively assess global and spatial information on the state of these second messenger effectors when coupled with gelbased assays, microscopy, or proteomics. Cysteines in some proteins can provide multiple levels of regulation such as the PRDX family. Not only are different PRDX family members spatially localized to distinct organelles, but the catalytic and resolving cysteines are also highly tuned to $\mathrm{H}_{2} \mathrm{O}_{2}$. Thus, analysis of the redox state of PRDX family cysteines can inform on local $\mathrm{H}_{2} \mathrm{O}_{2}$ levels throughout the cell even without microscopy or ROS assays (129).

There is strong evolutionary selection on cysteines. On one hand, negative selection due to their intrinsic oxidizability and reactivity has led cysteine to be the rarest amino acid. Perhaps more insightfully, cysteine is also the most buried amino acid despite its relative polar nature $(101,102)$. On the other hand, when cysteines do arise during evolution they typically carry a clear functional benefit and are seldom lost later $(171,184)$. As cysteines are rare, buried, and highly selected for specific function(s) in proteins, it follows that each cysteine could be considered a unique sentinel tuned to a set of context-specific factors informing on one or more redox modules $(18,80)$ (Fig. 4). Conceptually, cysteines bridge the systems-reductionist divide (151) since analysis of individual cysteines provides detailed biological information, but the cysteine redoxome can provide a systems-level readout of the cellular redox state when viewed globally. Notably, cysteine redoxome analysis can link altered redox state with specific proteins and biological pathways, which adds considerable mechanistic value over other redox assays $(20,38)$.

\section{Cysteine Redox Regulation: Properties and Mechanisms of Specificity in Redox Signaling Networks}

Properties of a cysteine affecting its oxidizability are proximity to the source of ROS (183), low acid dissociation constant (pKa) $(22,96,183)$, and solvent accessibility (102), which are necessary for direct interaction with a ROS. Redox regulation can also occur without direct interaction with ROS via disulfide relays (152, 161), transnitrosylation (64), or protein translocation to an organelle with a different redox setpoint (60). Notably, a subset of cysteines can be oxidized even in the absence of global changes to the antioxidant system (59) or detectable increase in $\operatorname{ROS}(20)$. This is due in part to the limited sensitivity of ROS assays and because the many endogenously redox-regulated cysteines are very reactive and highly tuned to the local redox milieu.

The oxidizability of a cysteine also depends on its neighbors. Kinetic competition, in which multiple potential reactions vie for a use of a reactant, is an important mechanism of

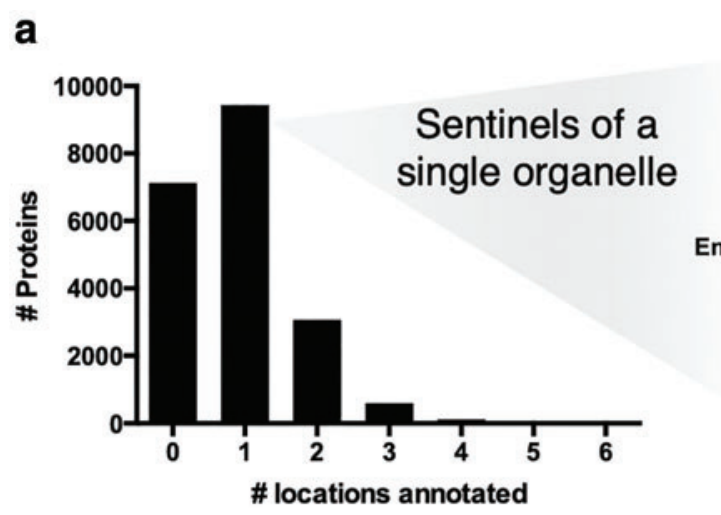

C Sentinel Proteins b

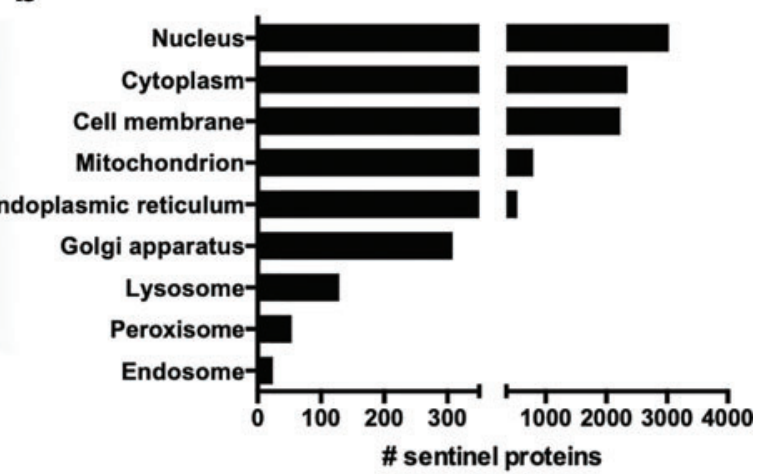

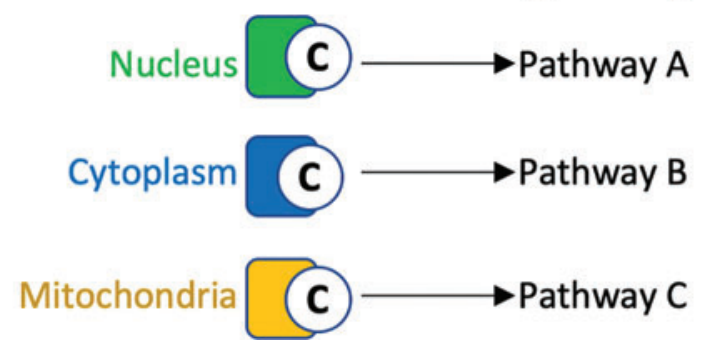

FIG. 3. Protein sentinels of subcellular compartments. (a) Distribution of the number of organelles assigned by the COMPARTMENTS database (19) to each human protein using the locations in (b). (b) Subcellular localization of all single organelle-localized protein sentinels. (c) Cysteines in sentinel proteins can indicate localized redox regulation of specific regulatory pathways. Color images are available online. 


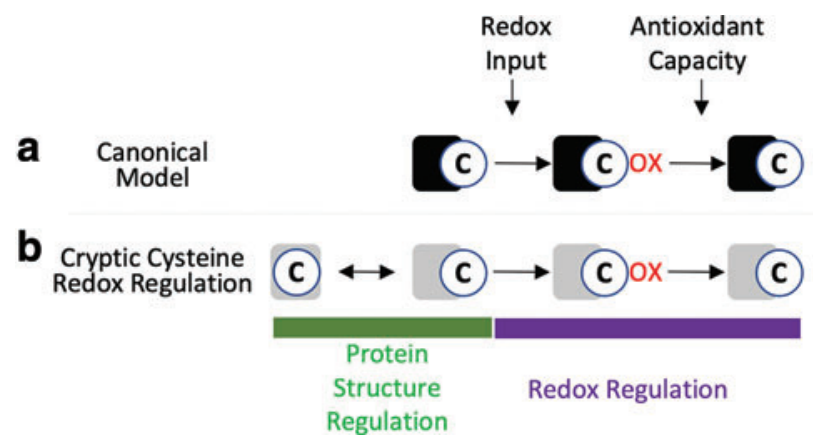

FIG. 4. Protein structural changes specify contextdependent regulation of the cysteine redoxome and redox signaling networks. (a) Cysteines are the targets of oxidation and reduction, and in the canonical model cysteines that are solvent accessible can be redox regulated. (b) Recent studies $(6,15,62)$ suggest that cryptic cysteines, those that become solvent exposed only upon a stimulus, can provide further context dependence of cysteine redox regulation via redox-independent changes in protein structure. Color images are available online.

redox selectivity in the complex cellular environment $(2,89$, 183). For example, PRDXs are abundant proteins that are highly reactive with $\mathrm{H}_{2} \mathrm{O}_{2}$, potentially outcompeting local sulfenation of most other cysteines intracellularly $(89,149$, $162,170)$. Once oxidized, a PRDX can subsequently form a disulfide relay with neighboring proteins in a relatively specific interaction $(150,152,161)$. Thus, protein-protein interactions also dictate redox regulation of a protein. Notably, kinetic modeling of the PRDX2-STAT3 disulfide relay suggests that its slow transfer kinetics are unfavorable in the context of potential competing reactions in the cell (89). The authors reconcile their results with published experimental findings (149) by re-evaluating the PRDX disulfide relay mechanism, and hypothesize that it may be facilitated by a third, scaffolding component. Transnitrosylation has also been reported to selectively relay a nitrosyl group from one cysteine to another in a protein (111).

The oxidizability of cysteines also depends on the type of ROS. For example, PRDXs are especially sensitive to $\mathrm{H}_{2} \mathrm{O}_{2}$, whereas aconitase and other iron sulfur $(\mathrm{Fe}-\mathrm{S})$ cluster containing proteins are more sensitive to $\mathrm{O}_{2}^{-\bullet}(169,179)$. Global proteomic studies focused on analysis of specific cysteine oxoforms have established that the selectivity of certain cysteines for certain redox effectors is widespread, including $\bullet \mathrm{NO}, \mathrm{GSH}$, and $\mathrm{H}_{2} \mathrm{O}_{2}$ (62).

While the magnitude of cysteine oxidation is generally closely correlated with ROS levels, each cysteine oxoform has unique kinetics and selectivity for individual cysteine residues (138). Modeling the kinetics of cysteine sulfenic acid $(\mathrm{SOH})$ formation serves as an example, which explains counterintuitive experimental results. Cysteine $\mathrm{SOH}$ is the direct oxidation product of cysteine with $\mathrm{H}_{2} \mathrm{O}_{2}$. Therefore, $a$ priori, levels of $\mathrm{H}_{2} \mathrm{O}_{2}$ might be hypothesized to correlate directly with levels of cysteine SOH (Fig. 5a). However, empirically this is not observed; as increased exogenous $\mathrm{H}_{2} \mathrm{O}_{2}$ and epidermal growth factor (EGF) stimulation results in a biphasic change in $\mathrm{SOH}$ levels, increasing to a tipping point, beyond which increased $\mathrm{H}_{2} \mathrm{O}_{2}$ decreases $\mathrm{SOH}$ levels $(120,133)$. Kinetic modeling can explain these nonlinear, counterintuitive results. Inclusion of cysteine sulfinic acid $\left(\mathrm{SO}_{2} \mathrm{H}\right)$, the reaction product of $\mathrm{SOH}+\mathrm{H}_{2} \mathrm{O}_{2}$, into the kinetic model fits the observed biphasic response of $\mathrm{SOH}$ to $\mathrm{H}_{2} \mathrm{O}_{2}$ treatment (Fig. 5b). This example underscores how simple network models can guide intuitive understanding of unexpected, but fundamentally important properties of redox biology as well as emphasizes that redox processes are rarely linear. Importantly, while $\mathrm{SOH}$ levels do not parallel $\mathrm{H}_{2} \mathrm{O}_{2}$ levels, assaying sulfenation of the cysteine redoxome output is potentially more meaningful as it indicates the transition point of sulfenation to sulfination $\left(\mathrm{SO}_{2} \mathrm{H}\right)$ and more accurately represents the oxidation of downstream $\mathrm{H}_{2} \mathrm{O}_{2}$ protein effectors.

The design principles of cysteine redox networks are most thoroughly understood by examining EGF signaling (Fig. 6), the best characterized model of redox signaling $(120,188)$ whose study was initiated by insulin receptor signaling decades earlier $(21,33,104)$. Growth factor signaling highlights the importance of coordination to redox regulation, and includes both concerted oxidation of multiple cysteines in proteins and codependence with redox-independent processes to elicit specificity. The first principle is the importance of a spatially constrained source of ROS. In the case of EGF, this is activation of NOX or DUOXs at the plasma membrane $(26,60,120)$. Second is the spatial specificity of the $\mathrm{O}_{2}^{-\bullet}$ and $\mathrm{H}_{2} \mathrm{O}_{2}$ produced by rapid intracellular degradation of ROS that limits their diffusion distance $(95,103,120$, a
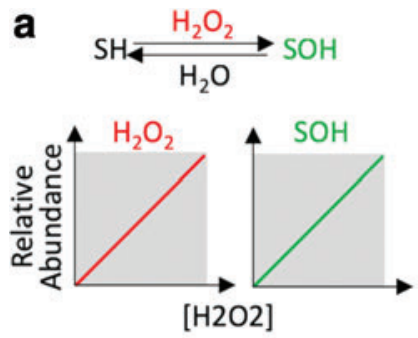

b
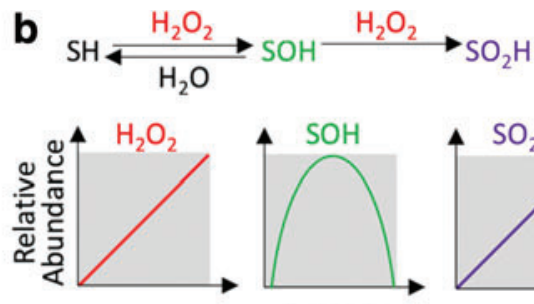

[H2O2]

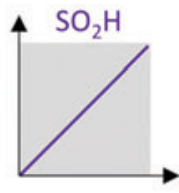

FIG. 5. Nonintuitive, nonlinear redox regulation of cysteine sulfenation by $\mathrm{H}_{2} \mathrm{O}_{2}$. (a) In a kinetic model including only $\mathrm{H}_{2} \mathrm{O}_{2}$ and cysteine sulfenation ( $\mathrm{SOH}$ ), the concentrations of $\left[\mathrm{H}_{2} \mathrm{O}_{2}\right]$ and $[\mathrm{SOH}]$ are directly related. While intuitive, this does not fit the empirical results in which $\mathrm{H}_{2} \mathrm{O}_{2}$ is biphasic, increasing [SOH] up to a point, beyond which [SOH] decreases. (b) Inclusion of cysteine sulfination $\left(\mathrm{SO}_{2} \mathrm{H}\right)$, the reaction product of $\mathrm{SOH}+\mathrm{H}_{2} \mathrm{O}_{2}$, generates the observed biphasic relationship of $[\mathrm{SOH}]$ to $\left[\mathrm{H}_{2} \mathrm{O}_{2}\right] . \mathrm{H}_{2} \mathrm{O}_{2}$, hydrogen peroxide. Color images are available online. 
a

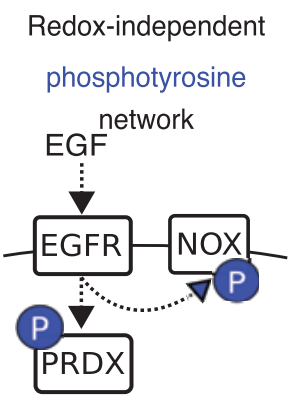

b

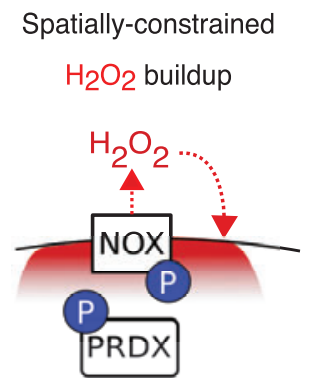

\section{C}

Concerted redox

regulation of the

cysteine redoxome

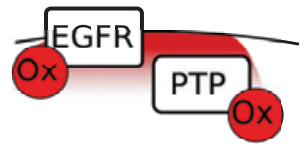

Time

FIG. 6. Temporal separation of redox-dependent and -independent events is a key design principle of the EGFR signaling network. (a) Redox-dependent signaling is delayed from redox-independent signaling after EGF stimulation. EGF initially stimulates local phosphotyrosine signaling cascades, an important activator of NOX and inhibitor of PRDX activity, (b) delaying ROS production and spatially constraining the $\mathrm{H}_{2} \mathrm{O}_{2}$ produced to the plasma membrane. (c) Cysteines in multiple proteins, including EGFR and PTPs, are concertedly redox regulated. EGF, epidermal growth factor; EGFR, epidermal growth factor receptor; NOX, NADPH oxidase; PRDX, peroxiredoxin; PTP, protein tyrosine phosphatase. Color images are available online.

166). A third principle is the relatively short duration of altered redox state before returning to homeostasis (66), $<60 \mathrm{~min}$ in the case of EGF stimulation (120). Fourth, oxidation of multiple cysteines in several proteins is critical to tipping the balance toward EGF-dependent phosphorylation. Oxidation of the catalytic cysteine in protein tyrosine phosphatases decreases the brake on phosphotyrosine signaling (46), and oxidation of cysteine in the kinase domain of epidermal growth factor receptor (EGFR) increases its activity up to a point, above which its kinase activity decreases (120). Notably, there is selectivity in which phosphatases are oxidized since EGF is a poor oxidizer of PTP1B yet oxidizes SHP-2 at very low EGF levels (120). While there is no clear mechanistic explanation for this, it is likely to be contextdependent changes in the phosphatases rather than an intrinsic property of the phosphatase(s) themselves since insulin preferentially oxidizes PTP1B (67). A fifth design principle is the interdependence of redox-dependent and -independent events (15). EGF-dependent phosphotyrosine signaling occurs more rapidly than redox processes, peaking $\sim 1$ min after EGF stimulation $(32,115)$, whereas ROS production and cysteine $\mathrm{SOH}$ are delayed and maximal at $5 \mathrm{~min}$ (120). This delay is setup because EGF-dependent phosphorylation of NOX by SRC is required to trigger NOX activation and ROS production. SRC-dependent phosphorylation of Y194 of PRDX1 also locally deactivates it near the cell membrane (185), facilitating local buildup of $\mathrm{H}_{2} \mathrm{O}_{2}$ levels $(97,185)$. From a network perspective, redox signaling serves as an amplifier, rather than initiator, of EGF signaling, and the temporal delay of phosphatase and kinase regulation likely promotes ultrasensitivity of EGF signaling, sharpening the response to become more binary and less graded $(72,168)$.

The temporal separation of redox-independent and redoxdependent events plays a key role in specifying which cysteines are oxidized by EGF due to an emerging relationship between protein structure and oxidation of cryptic cysteines, those that are only solvent exposed upon changes in protein conformation $(6,15,75,86)$. It has been estimated that $40 \%-$
$70 \%$ of proteins are allosterically regulated and contain cryptic pockets $(29,114)$, and several studies have found that changes in protein folding can allosterically alter cysteine solvent accessibly $(13,53)$. Redox regulation of cryptic cysteines was conclusively demonstrated by Alegre-Cebollada in which cell stretching mechanically unfolded the elastic protein titin and allowed several cysteines to become solvent exposed and glutathionylated (6). Redox regulation inhibited titin refolding, stabilizing the extended structure to impart a mechanically weak state, which decreased cardiomyocytes stiffness (6). More broadly, Gould et al. performed a redox proteomic analysis of $\sim 3000$ cysteines in mouse liver under steady state physiological conditions, and found that the cysteines oxidized at steady state had neither a low pKa nor were especially solvent accessible (62). A similar conclusion was reached in another large-scale profiling of redox-regulated cysteines (51). While this could be due to inaccurate $\mathrm{pKa}$ predictions, a similar prediction of the cysteines oxidized by $\mathrm{H}_{2} \mathrm{O}_{2}$ finds them to be largely solvent accessible in several studies (53, 188). A likely explanation is that endogenous ROS oxidizes cysteines that are solvent exposed at steady state, which is not reflected in crystal structures that are biased toward stable lowenergy conformers (146). Once a cryptic cysteine is oxidized, the surrounding apolar environment may stabilize it in the oxidized state (163). Alternatively, it has been proposed that hydrophobic ${ }^{\circ} \mathrm{NO}$ may be able to tunnel to buried cysteines surrounded by hydrophobic residues (18). Since most cysteines are buried due to negative selection $(101,102)$, redox regulation of cryptic cysteines provides a plausible mechanism specifying the context-dependent selectivity of redox signaling pathways (15) (Fig. 4).

Additional connections between protein structure and cysteine oxidation are notable. Thiol/disulfide exchange in proteins can be regulated by mechanical force and can be influenced by protein folding (182). Second, forbidden disulfides with relatively high disulfide redox potential that introduces strain into a protein's structure occur in many protein crystal structures and can serve as redox switches $(43,186)$. 
Together, the cysteine redoxome contains information integrating protein structural dynamics, redox-dependent and -independent regulation, as well as the location and levels of redox perturbations (Figs. 2-4). From the perspective of biological network design (168), cysteines serve inter alia as redox sniffers [transient responses, $(149,183,185)]$, toggles [hysteretic switches, (33)], amplifiers (120), blinkers [oscillators, $(38,39)]$, and feedback loops $(21,68)$. Importantly, cysteine oxidation, as compared with other assays, is uniquely suited to leverage new insights into the context dependence of redox biology by directly linking to downstream pathways. The next section details cysteine oxidation assays and the tools available to maximally harness these results, especially those from cysteine redox proteomics datasets.

\section{Techniques to Assay Cysteine Redox Regulation}

Numerous probes can directly and covalently tag specific cysteine oxoforms such as $\mathrm{SOH}(120,124,125), \mathrm{SO}_{2} \mathrm{H}(4)$, persulfide (117), and SNOs (139). Incorporating a clickable handle, such as an azide or alkyne, for one step conjugation to a wide array of detection modalities facilitates protein purification as well as in situ and in vivo imaging (187). Analysis of cysteine $\mathrm{SOH}$ oxoforms is the most mature, with $\mathrm{SOH}$ probes enabling imaging $(78,120,140)$ and detection of $>1000$ sulfenated cysteines by proteomics (188). Proteomics has also been performed using direct SNO probes (139). While there is no probe to chemically label endogenous GSH, cells can utilize biotinylated GSH ethyl ester in place of GSH (Bio-GEE), as well as more flexible, clickable GSH analogs $(44,79)$. Unfortunately, no technique is capable of labeling disulfide bonds directly or indirectly, thus large-scale profiling of the disulfideome is not currently feasible. However, disulfide relay partners can be identified via catalytic mutants that prevent resolution of the disulfide (112). One limitation of cysteine oxoform trapping probes is their slow reactivity and efficiency that, coupled with low endogenous modification stoichiometry, often dictates long (30-60 min) incubation times (188) and limits their utility for temporal profiling or assays that require substantial protein input. In addition, the specificity of several oxoform-directed probes has been questioned $(47,130,160)$.

While trapping cysteine oxoforms with probes can be coupled with mass spectrometry $(62,139,188)$, most redox proteomics utilize differential alkylation to tag all reversibly oxidized cysteines $(62,70)$ or selectively reduce specific oxoforms such as SNO $(50,62)$, S-GSH $(37,62)$, or persulfides (36). In the differential alkylation procedure, free thiols are first covalently labeled with an alkylating reagent such as iodoacetamide or $N$-ethylmaleimide (NEM), reversibly oxidized cysteines are then reduced, followed by labeling the now free cysteine thiols with a different alkylating agent to distinguish previously oxidized thiols (70). While information about specific oxoforms is often lost, the lack of selectivity may be advantageous from a systems biology perspective by being more inclusive and integrative. Differential alkylation studies also enable detection of more cysteines and thus more sentinels, casting a wider net that can be more fully leveraged for functional analysis and spatial determination of cellular redox changes $(15,62,128)$. Furthermore, since cells or tissues are rapidly lysed before differential labeling, a rapid snapshot of the redox state is acquired that enables assessment of cysteine oxidation dynamics with higher temporal precision compared with in situ trapping with covalent oxoform-specific tags (15).

Cysteine redox proteomics has been applied to many models, including oxidation analysis of $\sim 170$ peptides in Caenorhabditis elegans during development and aging (87), 1200 cysteines in Drosophila melanogaster under conditions of fasting and aging (105), 2100 cysteines in Synechocystis spp. PCC 6803 in light versus dark cycles (63), 2500 sites in mouse liver at steady state (62), and as many as $\sim 4500$ and $\sim 9500$ cysteines in yeast and mouse cells, respectively, upon oxidative stress (128). The magnitude of oxidation of the cysteine redoxome by endogenous perturbations is surprisingly widespread with $\sim 49 \%$ of cysteines detected having altered redox regulation by endogenous perturbation, including EGF stimulation, light-dark cycling, or fasting $(15,63,93,188)$. Despite the utility of redox proteomics to assess redox signaling, many redox proteomic studies continue to focus on models of oxidative stress $(8,27,128,173)$.

The cysteine proteome also contains reactivity and solvent accessibility information that is complementary to redox status. Cysteine protection assays have long been utilized to determine protein structural changes (1). Bar-Peled et al. adapted this approach to profile solvent accessible cysteines proteome wide in cultured cells using high levels of alkylating agents to fully label cysteines (13). Alternatively, Weerapana et al. utilized limiting doses of the alkylating reagent iodoacetamide to quantify the nucleophilicity of cysteine in the proteome (180). Nucleophilicity is correlated with pKa but is nonlinearly related to oxidizability (163). Petrova et al. profiled the reactivity of $\sim 6000$ cysteines in drosophila in the presence or absence of the ovary-specific TRX Deadhead using a similar alkylation approach (121).

Redox systems biology, like other systems-level analyses, is currently limited in practice more by the lack of data availability than computational power (172). Unfortunately, redox proteomics assays have limited throughput due to the multiple steps in sample preparation and data analysis. Therefore, generation of proteomic data is the primary bottleneck to proteome-level characterization of cysteine sentinels in the redoxome. Analysis of multiple oxoforms (62) expands the number of samples to analyzed, restricting the number of conditions that can be profiled and limiting characterization of the dynamics of the cysteine redoxome (176). Isotope encoded, cysteine-reactive iodoTMT reagents capable of six-plex sample analysis can improve throughput of sample analysis $(8,14,118,119,141)$ and can be optionally paired with N-terminally labeling TMT reagents to quantify protein expression changes in parallel $(14,119)$. Pairing matched stable-isotope encoded variants of alkylating reagents before and after reduction can estimate the oxidation stoichiometry of each cysteine detected $(63,69,70,91,145)$; however, absolute percentage oxidation has limited biological inference, and thus relative changes in oxidation levels are typically the focus of analysis.

Large-scale mass spectrometry-based proteomics are also limited by the dynamic range, roughly three orders of magnitude, which can be overcome by targeted mass spectrometry assays to improve sensitivity $(34,69)$. Multiple reaction monitoring mass spectrometry has been applied to quantify targeted cysteines in many proteins $(34,69)$. While a downside of targeted assays is quantitation of fewer analytes, 
new approaches using data-independent acquisition (DIA), also known as SWATH, and retention time scheduling analysis of targeted analytes across the liquid chromatography (LC) profile dramatically increase the number of analytes that can be measured in a single mass spectrometry run (15, 134). Notably, proteomic datasets using isobaric tags such as TMT often have up to $50 \%$ of quantitative data points missing. DIA mass spectrometry can quantify nearly all analytes detected in a sample, but can be more challenging to analyze $(30,71)$.

Bottom-up mass spectrometry-based proteomics often does not detect key cysteines. For example, the catalytic cysteines in protein tyrosine phosphatases and PRDXs are rarely detected due to their placement in poor tryptic peptides, low abundance, or low ionizability. Despite the progress of top-down proteomics (49), translating cysteine redox proteomics assays to a pure top-down format has many technologies hurdles. However, integration of top-down and bottom-up proteomics proved useful for post-translational modification (PTM) analysis of cancer samples and may increase the completeness of redox proteomics datasets (113). Alternatives to mass spectrometry-based proteomics, such as immobilized antibody arrays, have been used to rapidly profile the glutathionylation of 1000 proteins, many of them typically below the detection limit of mass spectrometry as an additional benefit (110). However, this approach is not able to determine which specific cysteine residues are oxidized.

Feature selection is an important challenge in redox biology given its high data dimensionality. While orthogonal assays, for example, temporal characterization and proteomics, may be an ideal pair, integrating disparate datasets can be challenging. Self-organizing maps have potential to visualize and classify high dimensional data (52). Network inference to conceptualize and simplify biological reality using coexpression or transcription regulatory networks has also shown promise (148), but for redox analyses these need continued advancements to include information about redox couples, PTMs, metabolites, and/or ROS. Thus, the most efficient approach to understand the redox landscapes and the network architecture of redox modules remains elusive.

\section{Redox-Regulated Cysteines: Predicting and Annotating Biochemical Properties}

The large-scale, site-specific information provided by redox proteomic analysis is advantageous for translating information about the cysteine redoxome to integrative knowledge of the cellular redox state. While cysteine redox profiling does not provide a full account of redox biology, each analysis generates an enormous amount of data that can be harnessed for multiparameter assessment of the redox state of cells using relatively user-friendly tools. Characterizing the properties of cysteine redox sentinels can be used to infer spatial information or ROS regulation independent of microscopy or ROS assays, and is valuable for feature selection and hypothesis generation. Available resources to annotate or predict the properties of individual cysteines and redoxregulated proteins are detailed here to maximize the information content of each cysteine and utilize it as an individual redox sensor. In some cases, this information is empirically determined and publicly available, and in other cases the properties require computational prediction. Tools that are open source are prioritized whenever possible as are those that are suitable for proteome-scale analysis, rather than analysis of a single cysteine or protein at a time.

Quantitative redox proteomics methods universally proteolyze proteins into peptides with trypsin before LC-mass spectrometry analysis. Thus, the first step of proteomic data analysis is assigning each peptide to a protein or proteins that include the peptide amino acid sequence. In many cases, peptides can be assigned to a single protein, but in some cases multiple proteins share a single peptide sequence. Peptide sequences shared between homologous genes, such as AKT isoforms, may offer valuable biological information similar to PTM-specific antibodies that cannot distinguish between highly conserved regulatory sites within gene families. However, if the peptide is shared between two unrelated proteins the peptide has far less utility. Most mass spectrometry-based proteomic analysis software, such as the open source and wellsupported MaxQuant (31), will indicate all proteins that can be assigned to a given peptide as well as the residue number of the modified cysteine that can be carried forward for further bioinformatic analysis.

Solvent accessibility and local protein domain information are important components of cysteine redox regulation. NetSurfP-2.0 uses deep learning to predict the relative surface accessibility, secondary structure, and disorder of all amino acids in a protein, and can process large batches of protein inputs (84). UniProtKB is a large, curated, database that contains and links to the naturally occurring and diseaserelevant variants of specific amino acids, known PTMs or role in metal binding, as well as the protein domain containing each cysteine. Since the entire UniProt database can be downloaded and readily parsed, it is amenable to proteome-wide annotation.

Protein structures can also inform about the potential role of cysteines. While visual analysis is necessarily low throughput, protein crystal and solution state nuclear magnetic resonance structures can be found in the protein data bank. Chimera is an open source and powerful visualization tool for protein structure analysis that is integrated with MODELLER to build homology models if no protein structure is available (189). Interactive, virtual reality visualization of redox PTMs on proteins has recently been reported, and is an exciting new option for protein visualization (98). Finally, predicting the structural consequence of cysteine oxidation using an existing crystal structure as a starting point can be performed with Forcefield_PTM, a web-based tool that includes many cysteine oxoforms (81). An important caveat of all protein structure analyses, however, is that the full extent of protein dynamics and modifications are not represented.

Cysteine $\mathrm{pKa}$, especially lowered $\mathrm{pKa}$ that can predispose a cysteine for oxidation $(22,96,183)$, is a key physicochemical property of each cysteine. A comparison of four methods to predict $\mathrm{pKa}$ benchmarked to experimentally determined values was recently evaluated, including the commonly used algorithm PROPKA (11). Unfortunately, all methods were found to be unreliable with $\mathrm{pH}$ deviations averaging 2.5-3 U from empirically observed values. Adding to the challenge of $\mathrm{pKa}$ prediction, all currently available tools are limited to analysis of a single protein structure. As an alternative approach, $\mathrm{pKa}$ is correlated with nucleophilicity and reactivity $(101,102)$, which can be empirically 
determined on a large scale at the level of specific cysteines. The reactivity of 1082 cysteines in breast cancer cell extracts has been profiled (180), providing a large-scale, empirically determined dataset as an alternative to $\mathrm{pKa}$. These data, along with other parameters, have facilitated sequence-based prediction algorithms of cysteine reactivity and oxidizability using machine learning $(155,175)$.

For protein localization annotation, UniProtKB references the COMPARTMENTS database, which combines experimental data, informatic predictions, and text mining (19). Over 9400 canonical human proteins, accounting for $46 \%$ of the human proteome, are annotated to a single major subcellular organelle in the UniProtKB that can be used as location sentinels of subcellular changes in redox state (Fig. 3a). These sentinels are mostly localized to the nucleus and cytoplasm, but numerous sentinels of even the peroxisome and endosome are annotated (Fig. 3b). The Human Protein Atlas also provides localization information based on antibody staining (159).

Numerous resources are available to assign the biological role(s) and function(s) of redox-regulated proteins. UniProtKB offers a curated description of protein function. The dependency map is generating genome-scale drug inhibition and gene deletion datasets to assess the functional dependency of genes in cancer models (164). Large-scale CRISPR screens coupled with high content imaging and reporter gene assays are being used to examine gene-dependent phenotypic changes at the organelle level (142). Protein interaction partners often provide orthogonal insight into the life of protein. The STRING database includes protein-protein interactions for $\sim 10$ million proteins that are based on a combination of in silico prediction, high-throughput experiments, text mining, and coexpression information (156). Alternatively, BioPlex is using high-throughput protein affinity purification mass spectrometry to empirically determine protein-protein interaction partners of $>2000$ bait proteins to generate a list of 70,000 experimentally verified protein-protein interactions (73). Full functional assessment of redox-regulated cysteines often includes site-directed mutagenesis, but this is a low-throughput approach that is importantly not applicable to enzymes in which the cysteine residue is directly involved in their activity $(82,85)$.

Pathway-level annotation of proteins can be performed with protein set enrichment analysis (90). Alternatively, peptides can be assigned to the gene level (178), and the more commonly utilized gene set enrichment analysis (153) can be used. Notably, since identification by proteomic technologies is biased toward abundant proteins, such as metabolic and ribosomal proteins, it is critical to include all detected proteins in over-representation analysis. Specifically, inputting list of significantly regulated proteins identified by proteomics to investigate their enrichment compared with the human proteome will provide minimally useful biological insight. In addition, since proteomics datasets contain many proteins, multiple-hypothesis correction of $p$-values by Benjamini-Hochberg or another method should be considered for differential expression analysis. While protein interaction maps can be difficult to meaningfully interpret, network inference algorithms are a systems biology tool to infer important subnetworks and focus analysis (99). Since cysteine oxidation is a protein PTM event at the level of a specific cysteine rather than a gene, pathway mapping of the modified residues remains challenging though several tools are pushing PTM pathway analysis forward (126, 131). While there is no complete database of known redox-regulated sites, ProteomeScout (108) and OXID (53) are large protein PTM databases that include oxidized cysteine sites that can be downloaded to determine which redox-regulated cysteines identified may be novel. Other tools are available to predict sites of cysteine sulfenation (5) and S-nitrosation (24).

\section{Cysteine Oxidation in the Clinic}

Antioxidant therapies have had mixed results in patients due to many factors, including the relatively poor reactivity of most antioxidants, a focus on ROS levels rather than redox circuitry, and the lack of good biomarkers of drug activity (25). Next generation redox therapeutic approaches targeting the source of ROS, such as NOX (157), or targeting a specific redox vulnerability of cancer cells with relatively nonspecific antioxidants, such as ascorbate (135), provide continued optimism for redox-based therapies.

Assaying the cysteine redoxome in vivo could provide information on the mechanism of drug action, identify biomarkers of drug efficacy, and delineate the altered redox networks in individual patients to tailor redox-based therapeutic strategies (25). Key questions are whether the redox state of a disease is personalized and whether it can be drugged to restore homeostasis. The Cys:CySS ratio can serve as a redox biomarker of cells, tissues, and plasma (61), and served as a peripheral biomarker of treatment response in epileptic rats treated with kainic acid or pilocarpine (94). For in vivo analysis of Cys:CySS or GSH:GSSG, plasma samples must be immediately alkylated to preserve the redox state and to prevent artifacts during sample analysis (77). Oxidation of serum albumin C34, its lone nondisulfide-linked cysteine that is the major plasma oxidant sink, has also demonstrated potential as a biomarker $(12,41)$. While only minimally invasive, plasma analysis of redox couples or a single cysteine is unlikely to provide much specificity about the underlying disease biology or drug action. In comparison, cysteine oxoform trapping probes coupled with positron emission tomography imaging would allow noninvasive, in vivo analysis of the cysteine redoxome with more information content; however, this has not been reported to date.

Tissue biopsies offer more flexible options for cysteine redox analysis though best results require consistent sample processing after harvesting to minimize differential effects due to hypoxia (106). The in vivo redox state of the thiolbased roGFP, representative of the cysteine redoxome generally, has been shown to be accurately preserved after snap freezing, cryosectioning, and immersion if the fast acting alkylating agent NEM is added immediately to prevent $e x$ vivo oxidation by atmospheric oxygen or fixation (54). As NEM alkylation is often the initial step of differential alkylation, downstream processing of tissue biopsies for biochemical assays or proteomics is similarly technically sound (70). While the dynamic nature of cysteine redox regulation may limit their utility as biomarkers, the availability of techniques to preserve their redox state likely makes them at least as robust assay targets for in vivo analysis in the clinic as ROS assays or redox couples. Development of new cysteine analysis tools for patient samples is needed, such as antibodies that recognize unique oxoforms localized to specific 
cysteine residues in target proteins that could be used for immunohistochemistry or enzyme-linked immunosorbent assay.

Drugs containing irreversible thiol reactive groups are being incorporated into the next generation of targeted therapies toward kinases EGFR or Bruton's tyrosine kinase to minimize drug resistance (136). Notably, it is estimated that up to $20 \%$ of EGFR C797 is sulfenated (120). Since oxidation of these cysteines blocks reactivity, the efficacy of these new inhibitors may depend on the redox state of the cysteines and assaying it may inform on drug efficacy.

\section{Concluding Remarks}

Redox signaling via cysteine sentinels plays a multifaceted role in biology despite the biochemical complexity, transience, and likelihood for deleterious stress that a priori seems insufficiently robust to be selected for critical cellular tasks (190). The prevalence of cysteine redox regulation may simply be an ancient, anachronistic holdover from the great oxidation event (39) that persists as an inevitable consequence of life or, rather, is sustained due to robust design principles that are still being elucidated. New insights into redox signaling and regulation of the cellular redox state can be gleaned by harnessing the network of individual cysteines in the redoxome as sensors of cellular redox state that bridges reductionist and systems-level perspectives.

\section{Funding Information}

The Held lab acknowledges funding and support from the CA200893, CA138308, CA202852, CA179452, CA200893, AB SCIEX, and the Diabetes Research Center at Washington University (DK020579).

\section{References}

1. Abramczyk O, Rainey MA, Barnes R, Martin L, and Dalby $\mathrm{KN}$. Expanding the repertoire of an ERK2 recruitment site: cysteine footprinting identifies the D-recruitment site as a mediator of Ets-1 binding. Biochemistry 46: 9174-9186, 2007.

2. Adimora NJ, Jones DP, and Kemp ML. A Model of redox kinetics implicates the thiol proteome in cellular hydrogen peroxide responses. Antioxid Redox Signal 13: 731-743, 2010.

3. Akavia UD, Litvin O, Kim J, Sanchez-Garcia F, Kotliar D, Causton HC, Pochanard P, Mozes E, Garraway LA, and Pe'Er D. An integrated approach to uncover drivers of cancer. Cell 143: 1005-1017, 2010.

4. Akter S, Fu L, Jung Y, Conte M Lo, Lawson JR, Lowther WT, Sun R, Liu K, Yang J, and Carroll KS. Chemical proteomics reveals new targets of cysteine sulfinic acid reductase. Nat Chem Biol 14: 995-1004, 2018.

5. Al-barakati HJ, McConnell EW, Hicks LM, Poole LB, Newman RH, and Kc DB. SVM-SulfoSite: a support vector machine based predictor for sulfenylation sites. Sci Rep 8: 11288, 2018.

6. Alegre-Cebollada J, Kosuri P, Giganti D, Eckels E, RivasPardo JA, Hamdani N, Warren CM, Solaro RJ, Linke WA, and Fernández JM. S-glutathionylation of cryptic cysteines enhances titin elasticity by blocking protein folding. Cell 156: 1235-1246, 2014.

7. Anastasiou D, Poulogiannis G, Asara JM, Boxer MB, Jiang JK, Shen M, Bellinger G, Sasaki AT, Locasale JW,
Auld DS, Thomas CJ, Vander Heiden MG, and Cantley LC. Inhibition of pyruvate kinase M2 by reactive oxygen species contributes to cellular antioxidant responses. Science 334: 1278-1283, 2011.

8. Araki K, Kusano H, Sasaki N, Tanaka R, Hatta T, Fukui $\mathrm{K}$, and Natsume T. Redox sensitivities of global cellular cysteine residues under reductive and oxidative stress. $J$ Proteome Res 15: 2548-2559, 2016.

9. Ashok BT and Ali R. The aging paradox: free radical theory of aging. Exp Gerontol 34: 293-303, 1999.

10. Auclair JR, Brodkin HR, D'Aquino JA, Petsko GA, Ringe $\mathrm{D}$, and Agar JN. Structural consequences of cysteinylation of $\mathrm{Cu} / \mathrm{Zn}$-superoxide dismutase. Biochemistry 52: 61456150, 2013.

11. Awoonor-Williams E and Rowley CN. Evaluation of methods for the calculation of the $\mathrm{pKa}$ of cysteine residues in proteins. J Chem Theory Comput 12: 4662-4673, 2016.

12. Bar-Or D, Heyborne KD, Bar-Or R, Rael LT, Winkler J V., and Navot D. Cysteinylation of maternal plasma albumin and its association with intrauterine growth restriction. Prenat Diagn 25: 245-249, 2005.

13. Bar-Peled L, Kemper EK, Suciu RM, Vinogradova EV, Backus KM, Horning BD, Paul TA, Ichu TA, Svensson RU, Olucha J, Chang MW, Kok BP, Zhu Z, Ihle NT, Dix MM, Jiang P, Hayward MM, Saez E, Shaw RJ, and Cravatt BF. Chemical proteomics identifies druggable vulnerabilities in a genetically defined cancer. Cell 171: 696-709.e23, 2017.

14. Behring JB, Kumar V, Whelan SA, Chauhan P, Siwik DA, Costello CE, Colucci WS, Cohen RA, McComb ME, and Bachschmid MM. Does reversible cysteine oxidation link the Western diet to cardiac dysfunction? FASEB J 28: 1975-1987, 2014.

15. Behring JB, van der Post S, Mooradian AD, Egan MJ, Zimmerman MI, Clements JL, Bowman GR, and Held JM. Spatial and temporal alterations in protein structure by EGF regulate cryptic cysteine oxidation. bioRxiv 624304, 2019.

16. Benfeitas R, Selvaggio G, Antunes F, Coelho PMBM, and Salvador A. Hydrogen peroxide metabolism and sensing in human erythrocytes: a validated kinetic model and reappraisal of the role of peroxiredoxin II. Free Radic Biol Med 74: 35-49, 2014.

17. de Beus MD, Chung J, and Colón W. Modification of cysteine 111 in $\mathrm{Cu} / \mathrm{Zn}$ superoxide dismutase results in altered spectroscopic and biophysical properties. Protein Sci 13: 1347-1355, 2004.

18. Bignon E, Allega MF, Lucchetta M, Tiberti M, and Papaleo E. Computational structural biology of Snitrosylation of cancer targets. Front Oncol 8: 272, 2018.

19. Binder JX, Pletscher-Frankild S, Tsafou K, Stolte C, O'Donoghue SI, Schneider R, and Jensen LJ. Compartments: unification and visualization of protein subcellular localization evidence. Database 2014: bau012, 2014.

20. Brandes RP, Rezende F, and Schröder K. Redox regulation beyond ROS. Circ Res 123: 326-328, 2018.

21. Brigelius-Flohé $\mathrm{R}$ and Flohé L. Basic principles and emerging concepts in the redox control of transcription factors. Antioxid Redox Signal 15: 2335-2381, 2011.

22. Britto PJ, Knipling L, and Wolff J. The local electrostatic environment determines cysteine reactivity of tubulin. $J$ Biol Chem 277: 29018-29027, 2002.

23. Califano A and Alvarez MJ. The recurrent architecture of tumour initiation, progression and drug sensitivity. Nat Rev Cancer 17: 116-130, 2017. 
24. Carmona R, Claros M, and de Alché J. Bioinformatic prediction of S-nitrosylation sites in large protein datasets. Methods Mol Biol 1747: 241-250, 2018.

25. Chandel NS and Tuveson DA. The promise and perils of antioxidants for cancer patients. N Engl J Med 371: 177$178,2014$.

26. Chen K, Kirber MT, Xiao H, Yang Y, and Keaney JF. Regulation of ROS signal transduction by NADPH oxidase 4 localization. J Cell Biol 181: 1129-1139, 2008.

27. Chouchani ET, James AM, Methner C, Pell VR, Prime TA, Erickson BK, Forkink M, Lau GY, Bright TP, Menger KE, Fearnley IM, Krieg T, and Murphy MP. Identification and quantification of protein S-nitrosation by nitrite in the mouse heart during ischemia. J Biol Chem 292: 14486-14495, 2017.

28. Christodoulou D, Link H, Fuhrer T, Kochanowski K, Gerosa L, and Sauer U. Reserve flux capacity in the pentose phosphate pathway enables Escherichia coli's rapid response to oxidative stress. Cell Syst 6: 569-578.e7, 2018.

29. Cimermancic P, Weinkam P, Rettenmaier TJ, Bichmann L, Keedy DA, Woldeyes RA, Schneidman-Duhovny D, Demerdash ON, Mitchell JC, Wells JA, Fraser JS, and Sali A. CryptoSite: expanding the druggable proteome by characterization and prediction of cryptic binding sites. $J$ Mol Biol 428: 709-719, 2016.

30. Collins B, Hunter C, Liu Y, Schilling B, Rosenberger G, Bader S, Chan D, Gibson B, Gingras A, Held J, HirayamaKurogi M, Hou G, Krisp C, Larsen B, Lin L, Liu S, Molloy M, Moritz R, Ohtsuki S, Schlapbach R, Selevsek N, Thomas S, Tzeng S, Zhang H, and Aebersold R. Multilaboratory assessment of reproducibility, qualitative and quantitative performance of SWATH-mass spectrometry. Nat Commun 8: 291, 2017.

31. Cox J and Mann M. MaxQuant enables high peptide identification rates, individualized p.p.b.-range mass accuracies and proteome-wide protein quantification. Nat Biotechnol 26: 1367-1372, 2008.

32. Cuddihy SL, Winterbourn CC, and Hampton MB. Assessment of redox changes to hydrogen peroxide-sensitive proteins during EGF signaling. Antioxid Redox Signal 15: 167-174, 2011.

33. Czech MP, Lawrence JC, and Lynn WS. Evidence for the involvement of sulfhydryl oxidation in the regulation of fat cell hexose transport by insulin. Proc Natl Acad Sci U S A 71: 4173-4177, 1974.

34. Danielson SR, Held JM, Oo M, Riley R, Gibson BW, and Andersen JK. Quantitative mapping of reversible mitochondrial complex I cysteine oxidation in a Parkinson disease mouse model. J Biol Chem 286: 7601-7608, 2011.

35. Denicola GM, Karreth FA, Humpton TJ, Gopinathan A, Wei C, Frese K, Mangal D, Yu KH, Yeo CJ, Calhoun ES, Scrimieri F, Winter JM, Hruban RH, Iacobuzio-Donahue C, Kern SE, Blair IA, and Tuveson DA. Oncogeneinduced Nrf2 transcription promotes ROS detoxification and tumorigenesis. Nature 475: 106-110, 2011.

36. Dóka É, Pader I, Bíró A, Johansson K, Cheng Q, Ballagó K, Prigge JR, Pastor-Flores D, Dick TP, Schmidt EE, Arnér ESJ, and Nagy P. A novel persulfide detection method reveals protein persulfide- and polysulfidereducing functions of thioredoxin and glutathione systems. Sci Adv 2: e1500968, 2016.

37. Duan J, Kodali VK, Gaffrey MJ, Guo J, Chu RK, Camp DG, Smith RD, Thrall BD, and Qian WJ. Quantitative profiling of protein s-glutathionylation reveals redoxdependent regulation of macrophage function during nanoparticle-induced oxidative stress. ACS Nano 10: 524538, 2016.

38. Dwivedi G and Kemp ML. Systemic redox regulation of cellular information processing. Antioxid Redox Signal 16: 374-380, 2011.

39. Edgar RS, Green EW, Zhao Y, Van Ooijen G, Olmedo M, Qin X, Xu Y, Pan M, Valekunja UK, Feeney KA, Maywood ES, Hastings MH, Baliga NS, Merrow M, Millar AJ, Johnson CH, Kyriacou CP, O'Neill JS, and Reddy AB. Peroxiredoxins are conserved markers of circadian rhythms. Nature 485: 459-464, 2012.

40. Egea J, Fabregat I, Frapart YM, Ghezzi P, Görlach A, Kietzmann T, Kubaichuk K, Knaus UG, Lopez MG, Olaso-Gonzalez G, Petry A, Schulz R, Vina J, Winyard P, Abbas K, Ademowo OS, Afonso CB, Andreadou I, Antelmann H, Antunes F, Aslan M, Bachschmid MM, Barbosa RM, Belousov V, Berndt C, Bernlohr D, Bertrán E, Bindoli A, Bottari SP, Brito PM, Carrara G, Casas AI, Chatzi A, Chondrogianni N, Conrad M, Cooke MS, Costa JG, Cuadrado A, My-Chan Dang P, De Smet B, DebelecButuner B, Dias IHK, Dunn JD, Edson AJ, El Assar M, El-Benna J, Ferdinandy P, Fernandes AS, Fladmark KE, Förstermann U, Giniatullin R, Giricz Z, Görbe A, Griffiths H, Hampl V, Hanf A, Herget J, Hernansanz-Agustín P, Hillion M, Huang J, Ilikay S, Jansen-Dürr P, Jaquet V, Joles JA, Kalyanaraman B, Kaminskyy D, Karbaschi M, Kleanthous M, Klotz LO, Korac B, Korkmaz KS, Koziel R, Kračun D, Krause KH, Křen V, Krieg T, Laranjinha J, Lazou A, Li H, Martínez-Ruiz A, Matsui R, McBean GJ, Meredith SP, Messens J, Miguel V, Mikhed Y, Milisav I, Milković L, Miranda-Vizuete A, Mojović M, Monsalve M, Mouthuy PA, Mulvey J, Münzel T, Muzykantov V, Nguyen ITN, Oelze M, Oliveira NG, Palmeira CM, Papaevgeniou N, Pavićević A, Pedre B, Peyrot F, Phylactides M, Pircalabioru GG, Pitt AR, Poulsen HE, Prieto I, Rigobello MP, Robledinos-Antón N, Rodríguez-Mañas L, Rolo AP, Rousset F, Ruskovska T, Saraiva N, Sasson S, Schröder K8, Semen K, Seredenina T, Shakirzyanova A, Smith GL, Soldati T, Sousa BC, Spickett CM, Stancic A, Stasia MJ, Steinbrenner H, Stepanić V, Steven S, Tokatlidis K, Tuncay E, Turan B, Ursini F, Vacek J, Vajnerova O, Valentová K, Van Breusegem F, Varisli L, Veal EA, Yalçın AS, Yelisyeyeva O, Žarković N, Zatloukalová M, Zielonka J, Touyz RM, Papapetropoulos A, Grune T, Lamas S, Schmidt HHHW, Di Lisa F, and Daiber A. European contribution to the study of ROS: a summary of the findings and prospects for the future from the COST action BM1203 (EU-ROS). Redox Biol 13: 94-162, 2017.

41. Eriksson S, Prigge JR, Talago EA, Arnér ESJ, and Schmidt EE. Dietary methionine can sustain cytosolic redox homeostasis in the mouse liver. Nat Commun 6: 6479, 2015.

42. Fan J, Ye J, Kamphorst JJ, Shlomi T, Thompson CB, and Rabinowitz JD. Quantitative flux analysis reveals folatedependent NADPH production. Nature 510: 298-302, 2014.

43. Fan SW, George RA, Haworth NL, Feng LL, Liu JY, and Wouters MA. Conformational changes in redox pairs of protein structures. Protein Sci 18: 1745-1765, 2009.

44. Feng S, Chen Y, Yang F, Zhang L, Gong Y, Adilijiang G, Gao Y, and Deng H. Development of a clickable probe for profiling of protein glutathionylation in the central cellular 
metabolism of E. coli and Drosophila. Chem Biol 22: 1461-1469, 2015.

45. Finn NA, Findley HW, and Kemp ML. A switching mechanism in doxorubicin bioactivation can be exploited to control doxorubicin toxicity. PLoS Comput Biol 7: e1002151, 2011.

46. Flohé L, Brigelius-Flohé R, Saliou C, Traber MG, and Packer L. Redox regulation of NF-kappa B activation. Free Radic Biol Med 22: 1115-1126, 1997.

47. Forman HJ, Davies MJ, Krämer AC, Miotto G, Zaccarin $\mathrm{M}$, Zhang $\mathrm{H}$, and Ursini F. Protein cysteine oxidation in redox signaling: caveats on sulfenic acid detection and quantification. Arch Biochem Biophys 617: 26-37, 2017.

48. Forman HJ, Maiorino M, and Ursini F. Signaling functions of reactive oxygen species. Biochemistry 49: 835842, 2010.

49. Fornelli L, Toby TK, Schachner LF, Doubleday PF, Srzentić K, DeHart CJ, and Kelleher NL. Top-down proteomics: where we are, where we are going? J Proteomics 175: 3-4, 2018.

50. Forrester MT, Thompson JW, Foster MW, Nogueira L, Moseley MA, and Stamler JS. Proteomic analysis of Snitrosylation and denitrosylation by resin-assisted capture. Nat Biotechnol 27: 557-559, 2009.

51. Fowler NJ, Blanford CF, De Visser SP, and Warwicker J. Features of reactive cysteines discovered through computation: from kinase inhibition to enrichment around protein degrons. Sci Rep 7: 16338, 2017.

52. Fraser SJ and Dickson BL. A new method for data integration and integrated data interpretation: self-organising maps. Proceedings of Exploration 07 Fifth Decennial International Conference on Mineral Exploration. Toronto, Canada: 2007, pp. 907-910.

53. Fu L, Liu K, Sun M, Tian C, Sun R, Morales Betanzos C, Tallman KA, Porter NA, Yang Y, Guo D, Liebler DC, and Yang J. Systematic and quantitative assessment of hydrogen peroxide reactivity with cysteines across human proteomes. Mol Cell Proteomics 16: 1815-1828, 2017.

54. Fujikawa Y, Roma LP, Sobotta MC, Rose AJ, Diaz MB, Locatelli G, Breckwoldt MO, Misgeld T, Kerschensteiner M, Herzig S, Müller-Decker K, and Dick TP. Mouse redox histology using genetically encoded probes. Sci Signal 9: rs1, 2016.

55. Georgiou G. How to flip the (redox) switch. Cell 111: 607-610, 2002.

56. Giles NM, Giles GI, and Jacob C. Multiple roles of cysteine in biocatalysis. Biochem Biophys Res Commun 300: 1-4, 2003.

57. Go Y-M and Jones DP. Redox theory of aging: implications for health and disease. Clin Sci 131: 1669-1688, 2017.

58. Go Y-M, Roede JR, Walker DI, Duong DM, Seyfried NT, Orr M, Liang Y, Pennell KD, and Jones DP. Selective targeting of the cysteine proteome by thioredoxin and glutathione redox systems. Mol Cell Proteomics 12: 3285-3296, 2013.

59. Go YM, Gipp JJ, Mulcahy RT, and Jones DP. $\mathrm{H}_{2} \mathrm{O}_{2}$ dependent activation of GCLC-ARE4 reporter occurs by mitogen-activated protein kinase pathways without oxidation of cellular glutathione or thioredoxin-1. $J$ Biol Chem 279 5837-5845, 2004.
60. Go YM and Jones DP. Redox compartmentalization in eukaryotic cells. Biochim Biophys Acta 1780: 1273-1290, 2008.

61. Go YM and Jones DP. Cysteine/cystine redox signaling in cardiovascular disease. Free Radic Biol Med 50: 495-509, 2011.

62. Gould NS, Evans P, Martínez-Acedo P, Marino SM, Gladyshev VN, Carroll KS, and Ischiropoulos H. Sitespecific proteomic mapping identifies selectively modified regulatory cysteine residues in functionally distinct protein networks. Chem Biol 22: 965-975, 2015.

63. Guo J, Nguyen AY, Dai Z, Su D, Gaffrey MJ, Moore RJ, Jacobs JM, Monroe ME, Smith RD, Koppenaal DW, Pakrasi HB, and Qian W-J. Proteome-wide light/dark modulation of thiol oxidation in Cyanobacteria revealed by quantitative site-specific redox proteomics. Mol Cell Proteomics 13: 3270-3285, 2014.

64. Han X, Eckelman BP, Wang L, Yates JR, Lipton SA, Tzitzilonis C, Nakamura T, Holland EA, Clemente AT, Salvesen GS, Meng F, Riek R, Gu Z, Okamoto S, Scott FL, and Wong CCL. Transnitrosylation of XIAP regulates caspase-dependent neuronal cell death. Mol Cell 39: 184 $195,2010$.

65. Hanahan D and Weinberg RA. Hallmarks of cancer: the next generation. Cell 144: 646-674, 2011.

66. Hansen RE, Roth D, and Winther JR. Quantifying the global cellular thiol-disulfide status. Proc Natl Acad Sci U S A 106: 422-427, 2009.

67. Haque A, Andersen JN, Salmeen A, Barford D, and Tonks NK. Conformation-sensing antibodies stabilize the oxidized form of PTP1B and inhibit its phosphatase activity. Cell 147: 185-198, 2011.

68. Hawkins KE, Joy S, Delhove JMKM, Kotiadis VN, Fernandez E, Fitzpatrick LM, Whiteford JR, King PJ, Bolanos JP, Duchen MR, Waddington SN, and McKay TR. NRF2 orchestrates the metabolic shift during induced pluripotent stem cell reprogramming. Cell Rep 14: 18831891, 2016.

69. Held JM, Danielson SR, Behring JB, Atsriku C, Britton DJ, Puckett RL, Schilling B, Campisi J, Benz CC, and Gibson BW. Targeted quantitation of site-specific cysteine oxidation in endogenous proteins using a differential alkylation and multiple reaction monitoring mass spectrometry approach. Mol Cell Proteomics 9: 1400-1410, 2010.

70. Held JM and Gibson BW. Regulatory control or oxidative damage? Proteomic approaches to interrogate the role of cysteine oxidation status in biological processes. Mol Cell Proteomics 11: R111.013037, 2012.

71. Held JM, Schilling B, D'Souza AK, Srinivasan T, Behring JB, Sorensen DJ, Benz CC, and Gibson BW. Label-free quantitation and mapping of the ErbB2 tumor receptor by multiple protease digestion with data-dependent (MS1) and data-independent (MS2) acquisitions. Int J Proteomics 2013: 1-11, 2013.

72. Huang CY and Ferrell JE. Ultrasensitivity in the mitogenactivated protein kinase cascade. Proc Natl Acad Sci U S A 93: 10078-10083, 1996.

73. Huttlin EL, Bruckner RJ, Paulo JA, Cannon JR, Ting L, Baltier K, Colby G, Gebreab F, Gygi MP, Parzen H, Szpyt J, Tam S, Zarraga G, Pontano-Vaites L, Swarup S, White AE, Schweppe DK, Rad R, Erickson BK, Obar RA, Guruharsha KG, Li K, Artavanis-Tsakonas S, Gygi SP, 
and Harper JW. Architecture of the human interactome defines protein communities and disease networks. Nature 545: 505-509, 2017.

74. Jacob C, Giles GI, Giles NM, and Sies H. Sulfur and selenium: the role of oxidation state in protein structure and function. Angew Chem Int Ed Engl 42: 4742-4758, 2003.

75. Johnson CP, Tang HY, Carag C, Speicher DW, and Discher DE. Forced unfolding of proteins within cells. Science 317: 663-666, 2007.

76. Jones DP. Disruption of mitochondrial redox circuitry in oxidative stress. Chem Biol Interact 163: 38-53, 2006.

77. Jones DP and Liang Y. Measuring the poise of thiol/ disulfide couples in vivo. Free Radic Biol Med 47: 13291338, 2009.

78. Kaplan N, Urao N, Furuta E, Kim SJ, Razvi M, Nakamura Y, McKinney RD, Poole LB, Fukai T, and Ushio-Fukai M. Localized cysteine sulfenic acid formation by vascular endothelial growth factor: role in endothelial cell migration and angiogenesis. Free Radic Res 45: 1124-1135, 2011.

79. Kekulandara DN, Samarasinghe KTG, Munkanatta Godage DNP, and Ahn YH. Clickable glutathione using tetrazine-alkene bioorthogonal chemistry for detecting protein glutathionylation. Org Biomol Chem 14: 1088610893, 2016.

80. Kemp M, Go YM, and Jones DP. Nonequilibrium thermodynamics of thiol/disulfide redox systems: a perspective on redox systems biology. Free Radic Biol Med 44 921-937, 2008.

81. Khoury GA, Thompson JP, Smadbeck J, Kieslich CA, and Floudas CA. Forcefield-PTM: ab initio charge and AMBER forcefield parameters for frequently occurring posttranslational modifications. J Chem Theory Comput 9: 5653-5674, 2013.

82. Kim SF, Huri DA, and Snyder SH. Medicine: inducible nitric oxide synthase binds, S-nitrosylates, and activates cyclooxygenase-2. Science 310: 1966-1970, 2005.

83. Kippner LE, Finn NA, Shukla S, and Kemp ML. Systemic remodeling of the redox regulatory network due to RNAi perturbations of glutaredoxin 1, thioredoxin 1, and glucose-6-phosphate dehydrogenase. BMC Syst Biol 5: 164, 2011.

84. Klausen MS, Jespersen MC, Nielsen H, Jensen KK, Jurtz VI, Sønderby CK, Sommer MOA, Winther O, Nielsen M, Petersen B, and Marcatili P. NetSurfP-2.0: improved prediction of protein structural features by integrated deep learning. Proteins 87: 520-527, 2019.

85. Klomsiri C, Karplus PA, and Poole LB. Cysteine-based redox switches in enzymes. Antioxid Redox Signal 14: 1065-1077, 2010.

86. Klotzsch E, Smith ML, Kubow KE, Muntwyler S, Little WC, Beyeler F, Gourdon D, Nelson BJ, and Vogel V. Fibronectin forms the most extensible biological fibers displaying switchable force-exposed cryptic binding sites. Proc Natl Acad Sci U S A 106: 18267-18272, 2009.

87. Knoefler D, Thamsen M, Koniczek M, Niemuth NJ, Diederich AK, and Jakob U. Quantitative in vivo redox sensors uncover oxidative stress as an early event in life. Mol Cell 47: 767-776, 2012.

88. Kuehne A, Emmert H, Soehle J, Winnefeld M, Fischer F, Wenck H, Gallinat S, Terstegen L, Lucius R, Hildebrand $\mathrm{J}$, and Zamboni N. Acute activation of oxida- tive pentose phosphate pathway as first-line response to oxidative stress in human skin cells. Mol Cell 59: 359371, 2015.

89. Langford TF, Deen WM, and Sikes HD. A mathematical analysis of Prx2-STAT3 disulfide exchange rate constants for a bimolecular reaction mechanism. Free Radic Biol Med 120: 239-245, 2018.

90. Lavallée-Adam M, Rauniyar N, McClatchy DB, and Yates JR. PSEA-quant: a protein set enrichment analysis on label-free and label-based protein quantification data. $J$ Proteome Res 13: 5496-5509, 2014.

91. Leichert LI, Gehrke F, Gudiseva HV., Blackwell T, Ilbert M, Walker AK, Strahler JR, Andrews PC, and Jakob U. Quantifying changes in the thiol redox proteome upon oxidative stress in vivo. Proc Natl Acad Sci U S A 105: 8197-8202, 2008.

92. Lewis JE, Costantini F, Mims J, Chen X, Furdui CM, Boothman DA, and Kemp ML. Genome-scale modeling of NADPH-driven $\beta$-lapachone sensitization in head and neck squamous cell carcinoma. Antioxid Redox Signal 29: 937-952, 2018.

93. Li Y, Luo Z, Wu X, Zhu J, Yu K, Jin Y, Zhang Z, Zhao $S$, and Zhou L. Proteomic analyses of cysteine redox in high-fat-fed and fasted mouse livers: implications for liver metabolic homeostasis. J Proteome Res 17: 129_ 140, 2018.

94. Liang LP and Patel M. Plasma cysteine/cystine redox couple disruption in animal models of temporal lobe epilepsy. Redox Biol 9: 45-49, 2016.

95. Lim JB, Huang BK, Deen WM, and Sikes HD. Analysis of the lifetime and spatial localization of hydrogen peroxide generated in the cytosol using a reduced kinetic model. Free Radic Biol Med 89: 47-53, 2015.

96. Lim JC, Gruschus JM, Kim G, Berlett BS, Tjandra N, and Levine RL. A low pKa cysteine at the active site of mouse methionine sulfoxide reductase A. J Biol Chem 287: 25596-25601, 2012.

97. Lim JM, Lee KS, Woo HA, Kang D, and Rhee SG. Control of the pericentrosomal $\mathrm{H}_{2} \mathrm{O}_{2}$ level by peroxiredoxin I is critical for mitotic progression. J Cell Biol 210: 23-33, 2015.

98. Maes A, Martinez X, Druart K, Laurent B, Guégan S, Marchand $\mathrm{CH}$, Lemaire SD, and Baaden M. MinOmics, an integrative and immersive tool for multi-omics analysis. J Integr Bioinform 15: [Epub ahead of print]; DOI: 10.1515/jib-2018-0006, 2018.

99. De Maeyer D, Weytjens B, Renkens J, De Raedt L, and Marchal K. PheNetic: network-based interpretation of molecular profiling data. Nucleic Acids Res 43(W1): W244-W250, 2015.

100. Marbach D, Costello JC, Küffner R, Vega NM, Prill RJ, Camacho DM, Allison KR, Kellis M, Collins JJ, Aderhold A, Stolovitzky G, Bonneau R, Chen Y, Cordero F, Crane M, Dondelinger F, Drton M, Esposito R, Foygel R, De La Fuente A, Gertheiss J, Geurts P, Greenfield A, Grzegorczyk M, Haury A, Holmes B, Hothorn T, Husmeier D, Huynh-Thu V, Irrthum A, Karlebach G, Lèbre S, De Leo V, Madar A, Mani S, Mordelet F, Ostrer H, Ouyang Z, Pandya R, Petri T, Pinna A, Poultney C, Rezny S, Ruskin H, Saeys Y, Shamir R, Sîrbu A, Song M, Soranzo N, Statnikov A, Vega N, Vera-Licona P, Vert J, Visconti A, Wang $\mathrm{H}$, Wehenkel L, Windhager L, Zhang Y, and Zimmer R. Wisdom of crowds for robust gene network inference. Nat Methods 9: 796-804, 2012. 
101. Marino SM and Gladyshev VN. Cysteine function governs its conservation and degeneration and restricts its utilization on protein surfaces. J Mol Biol 404: 902-916, 2010.

102. Marino SM and Gladyshev VN. Analysis and functional prediction of reactive cysteine residues. J Biol Chem 287: 4419-4425, 2012.

103. Markvicheva KN, Bogdanova EA, Staroverov DB, Lukyanov S, and Belousov V V. Imaging of intracellular hydrogen peroxide production with HyPer upon stimulation of HeLa cells with EGF. Methods Mol Biol 1990: 85-91, 2019.

104. May JM and de Haën C. The insulin-like effect of hydrogen peroxide on pathways of lipid synthesis in rat adipocytes. J Biol Chem 254: 9017-9021, 1979.

105. Menger KE, James AM, Cochemé HM, Harbour ME, Chouchani ET, Ding S, Fearnley IM, Partridge L, and Murphy MP. Fasting, but not aging, dramatically alters the redox status of cysteine residues on proteins in Drosophila melanogaster. Cell Rep 11: 1856-1865, 2015.

106. Mertins P, Yang F, Liu T, Mani DR, Petyuk VA, Gillette MA, Clauser KR, Qiao JW, Gritsenko MA, Moore RJ, Levine DA, Townsend R, Erdmann-Gilmore P, Snider JE, Davies SR, Ruggles K V., Fenyo D, Kitchens RT, Li S, Olvera N, Dao F, Rodriguez H, Chan DW, Liebler D, White F, Rodland KD, Mills GB, Smith RD, Paulovich AG, Ellis M, and Carr SA. Ischemia in tumors induces early and sustained phosphorylation changes in stress kinase pathways but does not affect global protein levels. Mol Cell Proteomics 13: 1690-1704, 2014.

107. Le Moan N, Clement G, Le Maout S, Tacnet F, and Toledano MB. The Saccharomyces cerevisiae proteome of oxidized protein thiols: contrasted functions for the thioredoxin and glutathione pathways. J Biol Chem 281: 10420-10430, 2006.

108. Mooradian AD, Held JM, and Naegle KM. Using proteomescout: a resource of post-translational modifications, their experiments, and the proteins that they annotate. Curr Protoc Bioinformatics 2017: 13.32.113.32.27, 2017.

109. Moyer MW. The myth of antioxidants. Sci Am 24(1): 2025, 2015.

110. Mullen L, Seavill M, Hammouz R, Bottazzi B, Chan P, Vaudry D, and Ghezzi P. Development of "Redox Arrays" for identifying novel glutathionylated proteins in the secretome. Sci Rep 5: 14630, 2015.

111. Nakamura T, Wang L, Wong CCL, Scott FL, Eckelman BP, Han X, Tzitzilonis C, Meng F, Gu Z, Holland EA, Clemente AT, Okamoto SI, Salvesen GS, Riek R, Yates JR, and Lipton SA. Transnitrosylation of XIAP regulates caspase-dependent neuronal cell death. Mol Cell 39: 184-195, 2010.

112. Nakao LS, Everley RA, Marino SM, Lo SM, De Souza LE, Gygi SP, and Gladyshev VN. Mechanism-based proteomic screening identifies targets of thioredoxin-like proteins. J Biol Chem 290: 5685-5695, 2015.

113. Ntai I, LeDuc RD, Fellers RT, Erdmann-Gilmore P, Davies SR, Rumsey J, Early BP, Thomas PM, Li S, Compton PD, Ellis MJC, Ruggles K V., Fenyö D, Boja ES, Rodriguez H, Townsend RR, and Kelleher NL. Integrated bottom-up and top-down proteomics of patientderived breast tumor xenografts. Mol Cell Proteomics 15: 45-56, 2016.
114. Oates ME, Romero P, Ishida T, Ghalwash M, Mizianty MJ, Xue B, Dosztányi Z, Uversky VN, Obradovic Z, Kurgan L, Dunker AK, and Gough J. D2P2: database of disordered protein predictions. Nucleic Acids Res 41(D1): D508-D516, 2013.

115. Olsen JV, Blagoev B, Gnad F, Macek B, Kumar C, Mortensen P, and Mann M. Global, in vivo, and sitespecific phosphorylation dynamics in signaling networks. Cell 127: 635-648, 2006.

116. Orth JD, Thiele I, and Palsson BO. What is flux balance analysis? Nat Biotechnol 28: 245-248, 2010.

117. Pan J and Carroll KS. Persulfide reactivity in the detection of protein S-sulfhydration. ACS Chem Biol 8: 1110-1116, 2013.

118. Pan K-T, Chen Y-Y, Pu T-H, Chao Y-S, Yang C-Y, Bomgarden RD, Rogers JC, Meng T-C, and Khoo K-H. Mass spectrometry-based quantitative proteomics for dissecting multiplexed redox cysteine modifications in nitric oxide-protected cardiomyocyte under hypoxia. Antioxid Redox Signal 20: 1365-1381, 2014.

119. Parker J, Balmant K, Zhu F, Zhu N, and Chen S. cysTMTRAQ - an integrative method for unbiased thiol-based redox proteomics. Mol Cell Proteomics 14: 237-242, 2015.

120. Paulsen CE, Truong TH, Garcia FJ, Homann A, Gupta V, Leonard SE, and Carroll KS. Peroxide-dependent sulfenylation of the EGFR catalytic site enhances kinase activity. Nat Chem Biol 8: 57-64, 2012.

121. Petrova B, Liu K, Tian C, Kitaoka M, Freinkman E, Yang $\mathrm{J}$, and Orr-Weaver TL. Dynamic redox balance directs the oocyte-to-embryo transition via developmentally controlled reactive cysteine changes. Proc Natl Acad Sci U S A 115: E7978-E7986, 2018.

122. Pillay CS, Hofmeyr J-H, Mashamaite LN, and Rohwer JM. From top-down to bottom-up: computational modeling approaches for cellular redoxin networks. Antioxid Redox Signal 18: 2075-2086, 2012.

123. Pillay CS, Hofmeyr JHS, and Rohwer JM. The logic of kinetic regulation in the thioredoxin system. BMC Syst Biol 5: 15, 2011.

124. Poole LB, Zeng BB, Knaggs SA, Yakubu M, and King SB. Synthesis of chemical probes to map sulfenic acid modifications on proteins. Bioconjug Chem 16: 16241628, 2005.

125. Qian J, Wani R, Klomsiri C, Poole LB, Tsang AW, and Furdui CM. A simple and effective strategy for labeling cysteine sulfenic acid in proteins by utilization of $\beta$-ketoesters as cleavable probes. Chem Commun 48: 4091-4093, 2012.

126. Raaijmakers LM, Giansanti P, Possik PA, Mueller J, Peeper DS, Heck AJR, and Altelaar AFM. PhosphoPath: visualization of phosphosite-centric dynamics in temporal molecular networks. J Proteome Res 14: 4332-4341, 2015.

127. Reddie KG and Carroll KS. Expanding the functional diversity of proteins through cysteine oxidation. Curr Opin Chem Biol 12: 746-754, 2008.

128. Van Der Reest J, Lilla S, Zheng L, Zanivan S, and Gottlieb E. Proteome-wide analysis of cysteine oxidation reveals metabolic sensitivity to redox stress. Nat Commun 9: 1581, 2018.

129. Rhee SG, Woo HA, Kil IS, and Bae SH. Peroxiredoxin functions as a peroxidase and a regulator and sensor of local peroxides. J Biol Chem 287: 4403-4410, 2012. 
130. Ruddraraju KV, Parsons ZD, Llufrio EM, Frost NL, and Gates KS. Reactions of 1,3-diketones with a dipeptide isothiazolidin-3-one: toward agents that covalently capture oxidized protein tyrosine phosphatase 1B. J Org Chem 80: 12015-12026, 2015.

131. Rudolph JD and Cox J. A network module for the perseus software for computational proteomics facilitates proteome interaction graph analysis. J Proteome Res 18: 2052-2064, 2019.

132. Sallin O, Reymond L, Gondrand C, Raith F, Koch B, and Johnsson K. Semisynthetic biosensors for mapping cellular concentrations of nicotinamide adenine dinucleotides. Elife 7: pii:e32638, 2018.

133. Saurin AT, Neubert H, Brennan JP, and Eaton P. Widespread sulfenic acid formation in tissues in response to hydrogen peroxide. Proc Natl Acad Sci U S A 101: 17982 17987, 2004.

134. Schilling B, MacLean B, Held JM, Sahu AK, Rardin MJ, Sorensen DJ, Peters T, Wolfe AJ, Hunter CL, MacCoss MJ, and Gibson BW. Multiplexed, scheduled, highresolution parallel reaction monitoring on a full scan QqTOF instrument with integrated data-dependent and targeted mass spectrometric workflows. Anal Chem 87: 10222-10229, 2015.

135. Schoenfeld JD, Sibenaller ZA, Mapuskar KA, Wagner BA, Cramer-Morales KL, Furqan M, Sandhu S, Carlisle TL, Smith MC, Abu Hejleh T, Berg DJ, Zhang J, Keech J, Parekh KR, Bhatia S, Monga V, Bodeker KL, Ahmann L, Vollstedt S, Brown H, Kauffman EPS, Schall ME, Hohl RJ, Clamon GH, Greenlee JD, Howard MA, Schultz MK, Smith BJ, Riley DP, Domann FE, Cullen JJ, Buettner GR, Buatti JM, Spitz DR, and Allen BG. $\mathrm{O}_{2} \bullet-$ and $\mathrm{H}_{2} \mathrm{O}_{2}$-mediated disruption of $\mathrm{Fe}$ metabolism causes the differential susceptibility of NSCLC and GBM cancer cells to pharmacological ascorbate. Cancer Cell 31: 487-500.e8, 2017.

136. Schwartz PA, Kuzmic P, Solowiej J, Bergqvist S, Bolanos B, Almaden C, Nagata A, Ryan K, Feng J, Dalvie D, Kath JC, Xu M, Wani R, and Murray BW. Covalent EGFR inhibitor analysis reveals importance of reversible interactions to potency and mechanisms of drug resistance. Proc Natl Acad Sci U S A 111: 173-178, 2014.

137. Schwarzländer M, Dick TP, Meyer AJ, and Morgan B. Dissecting redox biology using fluorescent protein sensors. Antioxid Redox Signal 24: 680-712, 2016.

138. Selvaggio G, Coelho PMBM, and Salvador A. Mapping the phenotypic repertoire of the cytoplasmic 2-Cys peroxiredoxin - thioredoxin system. 1. Understanding commonalities and differences among cell types. Redox Biol 15: 297-315, 2018.

139. Seneviratne U, Nott A, Bhat VB, Ravindra KC, Wishnok JS, Tsai L-H, and Tannenbaum SR. S-nitrosation of proteins relevant to Alzheimer's disease during early stages of neurodegeneration. Proc Natl Acad Sci US A 113: 4152-4157, 2016.

140. Seo YH and Carroll KS. Profiling protein thiol oxidation in tumor cells using sulfenic acid-specific antibodies. Proc Natl Acad Sci U S A 106: 16163-16168, 2009.

141. Shakir S, Vinh J, and Chiappetta G. Quantitative analysis of the cysteine redoxome by iodoacetyl tandem mass tags. Anal Bioanal Chem 409: 3821-3830, 2017.

142. Shanks E, Ketteler R, and Ebner D. Academic drug discovery within the United Kingdom: a reassessment. Nat Rev Drug Discov 14: 510, 2015.
143. Sheikh-Ali M, Chehade JM, and Mooradian AD. The antioxidant paradox in diabetes mellitus. Am J Ther 18: 266-278, 2011.

144. Siedler S, Schendzielorz G, Binder S, Eggeling L, Bringer $\mathrm{S}$, and Bott M. SoxR as a single-cell biosensor for NADPH-consuming enzymes in Escherichia coli. ACS Synth Biol 3: 41-47, 2014.

145. Sievers S, Dittmann S, Jordt T, Otto A, Hochgräfe F, and Riedel K. Comprehensive redox profiling of the thiol proteome of Clostridium difficile. Mol Cell Proteomics 17: 1035-1046, 2018.

146. Sikic K, Tomic S, and Carugo O. Systematic comparison of crystal and NMR protein structures deposited in the protein data bank. Open Biochem J 4: 83-95, 2010.

147. Singh CK, Chhabra G, Ndiaye MA, Garcia-Peterson LM, Mack NJ, and Ahmad N. The role of sirtuins in antioxidant and redox signaling. Antioxid Redox Signal 28: 643661, 2017.

148. De Smet R and Marchal K. Advantages and limitations of current network inference methods. Nat Rev Microbiol 8: 717-729, 2010.

149. Sobotta MC, Liou W, Stöcker S, Talwar D, Oehler M, Ruppert T, Scharf, and Dick TP. Peroxiredoxin-2 and STAT3 form a redox relay for $\mathrm{H}_{2} \mathrm{O}_{2}$ signaling. Nat Chem Biol 11: 64-70, 2015.

150. Somyajit K, Gupta R, Sedlackova H, Neelsen KJ, Ochs F, Rask MB, Choudhary C, and Lukas J. Redox-sensitive alteration of replisome architecture safeguards genome integrity. Science 358: 797-802, 2017.

151. Sorger PK. A reductionist's systems biology: opinion. Curr Opin Cell Biol 17: 9-11, 2005.

152. Stöcker S, Oehler M, Ruppert T, Talwar D, Sobotta MC, Dick TP, Liou W, and Scharf AND. Peroxiredoxin-2 and STAT3 form a redox relay for $\mathrm{H}_{2} \mathrm{O}_{2}$ signaling. Nat Chem Biol 11: 64-70, 2014.

153. Subramanian A, Tamayo P, Mootha VK, Mukherjee S, Ebert BL, Gillette MA, Paulovich A, Pomeroy SL, Golub TR, Lander ES, and Mesirov JP. Gene set enrichment analysis: a knowledge-based approach for interpreting genome-wide expression profiles. Proc Natl Acad Sci U S A 102: 15545-15550, 2005.

154. Sullivan DM, Wehr NB, Fergusson MM, Levine RL, and Finkel T. Identification of oxidant-sensitive proteins: TNF- $\alpha$ induces protein glutathiolation. Biochemistry 39: 11121-11128, 2000.

155. Sun M-an, Zhang Q, Wang Y, Ge W, and Guo D. Prediction of redox-sensitive cysteines using sequential distance and other sequence-based features. $B M C$ Bioinformatics 17: 316, 2016.

156. Szklarczyk D, Morris JH, Cook H, Kuhn M, Wyder S, Simonovic M, Santos A, Doncheva NT, Roth A, Bork P, Jensen LJ, and Von Mering C. The STRING database in 2017: quality-controlled protein-protein association networks, made broadly accessible. Nucleic Acids Res 45(D1): D362-D368, 2017.

157. Teixeira G, Szyndralewiez C, Molango S, Carnesecchi S, Heitz F, Wiesel P, and Wood JM. Therapeutic potential of NADPH oxidase 1/4 inhibitors. Br J Pharmacol 174: 1647-1669, 2017.

158. Thamsen $\mathbf{M}$ and Jakob U. The redoxome. Proteomic analysis of cellular redox networks. Curr Opin Chem Biol 15: 113-119, 2011.

159. Thul PJ, Akesson L, Wiking M, Mahdessian D, Geladaki A, Ait Blal H, Alm T, Asplund A, Björk L, Breckels LM, 
Bäckström A, Danielsson F, Fagerberg L, Fall J, Gatto L, Gnann C, Hober S, Hjelmare M, Johansson F, Thul PJ, Akesson L, Wiking M, Mahdessian D, Geladaki A, Ait Blal H, Alm T, Asplund A, Björk L, Breckels LM, Bäckström A, Danielsson F, Fagerberg L, Fall J, Gatto L, Gnann C, Hober S, Hjelmare M, Johansson F, Lee S, Lindskog C, Mulder J, Mulvey CM, Nilsson P, Oksvold P, Rockberg J, Schutten R, Schwenk JM, Sivertsson A, Sjöstedt E, Skogs M, Stadler C, Sullivan DP, Tegel H, Winsnes C, Zhang C, Zwahlen M, Mardinoglu A, Pontén F, von Feilitzen K, Lilley KS, Uhlén M, and Lundberg E. A subcellular map of the human proteome. Science 356: eaal3321, 2017.

160. Tian H, Sakmar TP, and Huber T. A simple method for enhancing the bioorthogonality of cyclooctyne reagent. Chem Commun 52: 5451-5454, 2016.

161. Toledano MB, Hidalgo E, Vivancos AP, Ayte J, Castillo EA, Nicot C, and Biteau B. A cysteine-sulfinic acid in peroxiredoxin regulates $\mathrm{H}_{2} \mathrm{O}_{2}$-sensing by the antioxidant Pap1 pathway. Proc Natl Acad Sci U S A 102: 8875-8880, 2005.

162. Travasso RDM, Sampaio dos Aidos F, Bayani A, Abranches P, and Salvador A. Localized redox relays as a privileged mode of cytoplasmic hydrogen peroxide signaling. Redox Biol 12: 233-245, 2017.

163. Trost P, Fermani S, Calvaresi M, and Zaffagnini M. Biochemical basis of sulphenomics: how protein sulphenic acids may be stabilized by the protein microenvironment. Plant Cell Environ 40: 483-490, 2017.

164. Tsherniak A, Vazquez F, Montgomery PG, Weir BA, Kryukov G, Cowley GS, Gill S, Harrington WF, Pantel S, Krill-Burger JM, Meyers RM, Ali L, Goodale A, Lee Y, Jiang G, Hsiao J, Gerath WFJ, Howell S, Merkel E, Ghandi M, Garraway LA, Root DE, Golub TR, Boehm JS, and Hahn WC. Defining a cancer dependency map. Cell 170: 564-576.e16, 2017.

165. Tsuchiya Y, Peak-Chew SY, Newell C, Miller-Aidoo S, Mangal S, Zhyvoloup A, Bakovic' J, Malanchuk O, Pereira GC, Kotiadis V, Szabadkai G, Duchen MR, Campbell M, Cuenca SR, Vidal-Puig A, James AM, Murphy MP, Filonenko V, Skehel M, and Gout I. Biochem J 474: 2489-2508, 2017.

166. Tsutsumi R, Harizanova J, Stockert R, Schröder K, Bastiaens PIH, and Neel BG. Assay to visualize specific protein oxidation reveals spatio-temporal regulation of SHP2. Nat Commun 8: 466, 2017.

167. Tu BP, Kudlicki A, Rowicka M, and McKnight SL. Cell biology: logic of the yeast metabolic cycle: temporal compartmentalization of cellular processes. Science 310: 1152-1158, 2005.

168. Tyson JJ, Chen KC, and Novak B. Sniffers, buzzers, toggles and blinkers: dynamics of regulatory and signaling pathways in the cell. Curr Opin Cell Biol 15: 221-231, 2003.

169. Vásquez-Vivar J, Kalyanaraman B, and Kennedy MC. Mitochondrial aconitase is a source of hydroxyl radical. An electron spin resonance investigation. J Biol Chem 275: 14064-14069, 2000.

170. Vivancos AP, Castillo EA, Biteau B, Nicot C, Ayte J, Toledano MB, and Hidalgo E. A cysteine-sulfinic acid in peroxiredoxin regulates $\mathrm{H}_{2} \mathrm{O}_{2}$-sensing by the antioxidant Pap1 pathway. Proc Natl Acad Sci U S A 102: 8875-8880, 2005.
171. Van Vlijmen HWT, Gupta A, Narasimhan LS, and Singh J. A novel database of disulfide patterns and its application to the discovery of distantly related homologs. J Mol Biol 335: 1083-1092, 2004.

172. Voit EO and Kemp ML. So, you want to be a systems biologist? Determinants for creating graduate curricula in systems biology. IET Syst Biol 5: 70-79, 2011.

173. Walker AK, Gehrke F, Gudiseva H V., Strahler JR, Blackwell T, Ilbert M, Leichert LI, Jakob U, and Andrews PC. Quantifying changes in the thiol redox proteome upon oxidative stress in vivo. Proc Natl Acad Sci U S A 105: 8197-8202, 2008.

174. Walsh LA, Alvarez MJ, Sabio EY, Reyngold M, Makarov V, Mukherjee S, Lee KW, Desrichard A, Turcan S, Dalin MG, Rajasekhar VK, Chen S, Vahdat LT, Califano A, and Chan TA. An integrated systems biology approach identifies TRIM25 as a key determinant of breast cancer metastasis. Cell Rep 20: 16231640, 2017.

175. Wang H, Chen X, Li C, Liu Y, Yang F, and Wang C. Sequence-based prediction of cysteine reactivity using machine learning. Biochemistry 57: 451-460, 2018.

176. Wang J, Choi H, Chung NC, Cao Q, Ng DCM, Mirza B, Scruggs SB, Wang D, Garlid AO, and Ping P. Integrated dissection of cysteine oxidative post-translational modification proteome during cardiac hypertrophy. $J$ Proteome Res 17: 4243-4257, 2018.

177. Wang R-S, Oldham WM, Maron BA, and Loscalzo J. Systems biology approaches to redox metabolism in stress and disease states. Antioxid Redox Signal 29: 953-972, 2017.

178. Wang X, Mooradian AD, Petra EG, Zhang Q, Viner R, Davies SR, Huang KL, Bomgarden R, Van Tine BA, Shao J, Ding L, Li S, Ellis MJ, Rogers JC, Townsend RR, Fenyö D, and Held JM. Breast tumors educate the proteome of stromal tissue in an individualized but coordinated manner. Sci Signal 10: eaam8065, 2017.

179. Wang Y, Branicky R, Noë A, and Hekimi S. Superoxide dismutases: dual roles in controlling ROS damage and regulating ROS signaling. J Cell Biol 217 1915-1928, 2018.

180. Weerapana E, Wang C, Simon GM, Richter F, Khare S, Dillon MBD, Bachovchin DA, Mowen K, Baker D, and Cravatt BF. Quantitative reactivity profiling predicts functional cysteines in proteomes. Nature 468: 790-797, 2010.

181. Resat H, Petzold L, and Pettigrew MF. Kinetic modeling of biological systems. Methods Mol Biol 541: 311-335, 2009.

182. Wiita AP, Ainavarapu SRK, Huang HH, and Fernandez JM. Force-dependent chemical kinetics of disulfide bond reduction observed with single-molecule techniques. Proc Natl Acad Sci U S A 103: 7222-7227, 2006.

183. Winterbourn CC. Reconciling the chemistry and biology of reactive oxygen species. Nat Chem Biol 4: 278-286, 2008.

184. Wong JWH, Ho SYW, and Hogg PJ. Disulfide bond acquisition through eukaryotic protein evolution. Mol Biol Evol 28: 327-334, 2011.

185. Woo HA, Yim SH, Shin DH, Kang D, Yu DY, and Rhee SG. Inactivation of peroxiredoxin $\mathrm{i}$ by phosphorylation allows localized $\mathrm{H}_{2} \mathrm{O}_{2}$ accumulation for cell signaling. Cell 140: 517-528, 2010. 
186. Wouters MA, Fan SW, and Haworth NL. Disulfides as redox switches: from molecular mechanisms to functional significance. Antioxid Redox Signal 12: 53-91, 2010.

187. Xie R, Dong L, Huang R, Hong S, Lei R, and Chen X. Targeted imaging and proteomic analysis of tumorassociated glycans in living animals. Angew Chem Int Ed Engl 53: 14082-14086, 2014.

188. Yang J, Gupta V, Carroll KS, and Liebler DC. Site-specific mapping and quantification of protein S-sulphenylation in cells. Nat Commun 5: 4776, 2014.

189. Yang Z, Lasker K, Schneidman-Duhovny D, Webb B, Huang CC, Pettersen EF, Goddard TD, Meng EC, Sali A, and Ferrin TE. UCSF Chimera, MODELLER, and IMP: an integrated modeling system. J Struct Biol 179: 269-278, 2012.

190. Yoshida K and Hisabori T. Two distinct redox cascades cooperatively regulate chloroplast functions and sustain plant viability. Proc Natl Acad Sci U S A 113: E3967-E3976, 2016.

191. Zhang J, Sonnenschein N, Pihl TPB, Pedersen KR, Jensen $\mathrm{MK}$, and Keasling JD. engineering an NADPH/NADP+ redox biosensor in yeast. ACS Synth Biol 5: 1546-1556, 2016.

192. Zhang L, King E, Luo R, and Li H. Development of a high-throughput, in vivo selection platform for NADPHdependent reactions based on redox balance principles. ACS Synth Biol 7 1715-1721, 2018.

193. Zou Y, Wang A, Shi M, Chen X, Liu R, Li T, Zhang C, Zhang Z, Zhu L, Ju Z, Loscalzo J, Yang Y, and Zhao Y. Analysis of redox landscapes and dynamics in living cells and in vivo using genetically encoded fluorescent sensors. Nat Protoc 13: 2362-2386, 2018.

Address correspondence to:

Dr. Jason M. Held

Department of Medicine

Washington University School of Medicine

660 South Euclid Avenue

Campus Box 8076

Saint Louis, MO 63110

E-mail: jheld@wustl.edu

Date of first submission to ARS Central, January 7, 2019; date of final revised submission, July 30, 2019; date of acceptance, July 30, 2019.

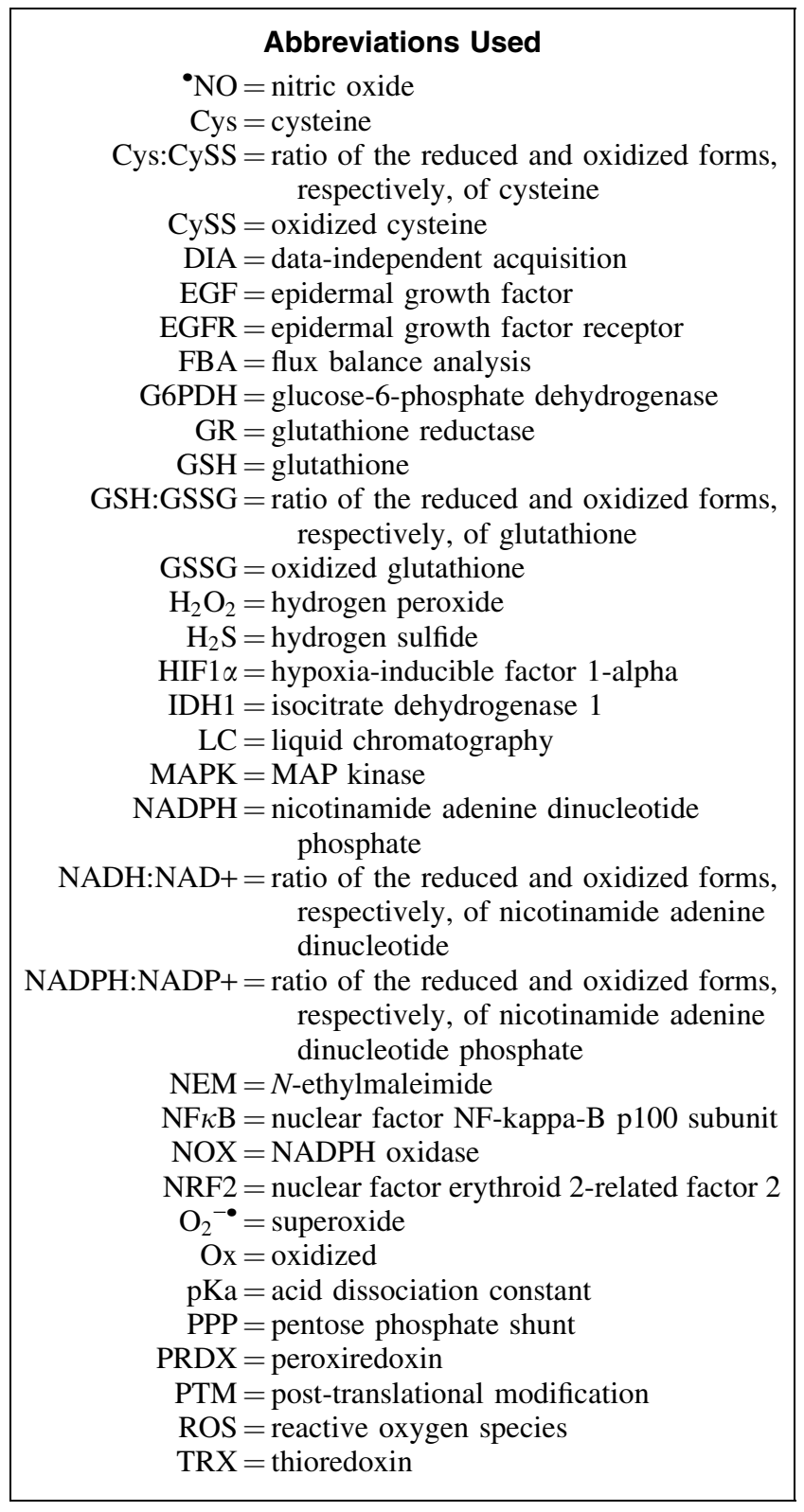

